\title{
Muhammad's Social Justice or Muslim Cant?: Langdellianism and the Failures of Islamic Finance
}

\author{
Haider Ala Hamoudi $\uparrow$
}

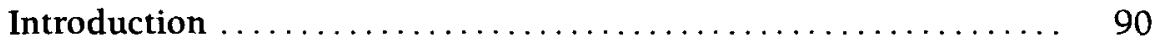

I. The Rise and Fall of Langdellian Legal Orthodoxy ....... 98

A. Langdellian Methodology and Attendant Implications ... 98

B. The Failures of Langdellianism in the Modern Era ..... 99

II. Langdellian Modalities in the Islamic Experience ........ 100

A. Historical Qualification ..................... 100

B. Shafi'i and the Formalist Modalities in the Methodology of Hadith Reporting ........................ 103

C. Shafi'i's Reductionist Interpretive Controls in the Emerging Formalist Modality .................. 105

D. Anti-formalism and the Langdellian Modality ........ 108

1. Istihsan .................................. 108

2. Istislah............................. 109

E. Demonstrations of Langdellianism: The Problems of Riba and Gharar in the Formalist Modalities ......... 109

1. Contours of the Riba Proscription ............... 111

2. Gharar.............................. 114

III. The Failures of Islamic Commercial Jurisprudence-The

Consequences of Langdellianism ................... 116

A. Original Conceptions $\ldots \ldots \ldots \ldots \ldots \ldots \ldots \ldots \ldots, 116$

B. Alternative Approaches Within the Langdellian

Modalities .................................. 118

1. Murabaha............................ 119

2. $\quad$ Ijara .................................. 120

3. Istisna'/Salam ......................... 121

4. A Problem of Insurance ..................... 122

C. Langdellianism and Islamic Finance .............. 124

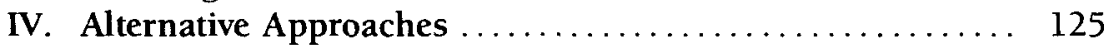

A. Qur'anic Maxims........................ 126

B. The Roles of Hadith, Istihsan, and Istislah: An

Examination of Sanhuri and Sadr ................ 127

1. Sanhuri's Definitional Approach ............... 128

$\dagger$ Associate in Law, Columbia Law School. The author would like to thank Abdullahi An-Na'im, Mark Cammack, Michael Dorf, Bernard Freamon, George Fletcher, Hoi Kong and Clark Lombardi for their comments and substantial support. Any errors are solely the author's responsibility.

40 CORNELl INT'L L.J. 89 (2007) 
2. Sadr's Contextual Approach

C. Assertion of Interpretive Control within an Alternative Modality ....

1. A Problem of "Subjectivity".................. 131

2. Proposed Synthesis of Definitionalism and Contextualism .......................... 131

D. Fairness and Social Justice in an Islamic Context...... 132 Conclusion

And We sent you not, Save in Mercy to the Peoples of the World. QUR'AN 21:07.

\section{Introduction}

Islamic finance has failed to achieve its most basic and central objectives, but the causes of that failure, and whether anything can be done to reconstruct the practice in a manner consistent with commercial reality and its ontology, are matters that, by and large, have gone unexamined. To understand the nature and depth of the failure, it may be useful to consider the following three simple examples.

First, a Muslim entrepreneur seeks short-term financing, knowing that any transaction involving the payment of interest on debt is forbidden under the rules of the shari'a, defined for purposes of this Article as Islamic law. ${ }^{1}$ She enters into a contract with an Islamic bank, pursuant to which the bank purchases a readily fungible commodity and simultaneously resells it to the entrepreneur at a mark-up, to be paid in three months' time. The mark-up corresponds precisely to the prevailing market interest rate. The bank never retains title to the commodity and the entrepreneur waives all claims as to breach of warranty against the bank, while the bank assigns to the entrepreneur all such rights it had against the original seller. Immediately upon taking possession of the commodity, the entrepreneur resells it at market value, leaving her with a sum certain and an obligation to pay a higher amount in the future. ${ }^{2}$

Second, a Muslim airline company wishes to finance the purchase of an aircraft, again heedful of the Islamic prohibition against interest. An Islamic bank purchases the aircraft company through an intermediate vehicle funded by the bank's financing and equity contributions. The intermediary then exacts from the airline a "lease rate" pegged to the prevailing market interest rate. The lease is "renewed" semi-annually for a period of twelve years, and the lease rate re-pegged at the time of renewal. However, the contract indicates that no party is permitted to withdraw or fail to

1. The basis for this ban is discussed extensively in Section II.E of this Article.

2. A transaction of this sort, albeit without the final resale back to the original seller, is described in greater detail in Umar F. Moghul \& Arshad A. Ahmed, Contractual Forms In Islamic Finance Law and Islamic Inv. Co. of the Gulf v. Symphony Gems N.V. E Ors.: A First Impression Of Islamic Finance, 27 Fordham INT'L L.J. 150 (2003). 
renew prior to the expiration of the twelve year period. The lease includes a provision indicating that New York law governs the transaction. ${ }^{3}$

Third, a Muslim shopkeeper needs to insure his store against casualty risks, notwithstanding the alleged shari'a prohibition against insurance. ${ }^{4}$ Therefore, an Islamic financial institution offers him an alternative; namely, an allegedly "charitable" instrument whereby he "donates" a set amount each month corresponding to a premium, which is then kept in his name at the institution. Other Muslim participants in the scheme offer similar donations. When a payout to one of the participants becomes necessary due to a qualifying event, the agreements stipulate that the financial institution withdraws the requisite amount from the aggregate donations and distributes the funds to the participant in question. The donated funds are invested in profit making ventures and gains are shared by the beneficiaries and the financial institution.

The first of these is a particularly egregious example ${ }^{5}$ of what is known as a murabaha transaction, which dominates the landscape of Islamic finance today. Over $80 \%$ of the current transactions by volume in Islamic banks are of a murabaha model. ${ }^{6}$ The second example, known as an ijara transaction, is a newer and rapidly growing segment of the Islamic financial sector. ${ }^{7}$ The third is known as takaful, frequently lauded as an example of Islamic financial innovation. ${ }^{8}$

It should also be obvious that all three of these transactions are largely artificial. They are substantively the same as their forbidden counterparts, albeit with semantic alterations and higher transaction costs associated with creating the appearance of difference. "Charitable insurance" is nonsense, as are simultaneous purchases and re-sales and renewable leases with no option but to renew. These are awkward constructs to circumvent, in a fundamentally disingenuous fashion, central prohibitions developed by the shari'a.

3. For greater exposition on the application of Islamic principles to modern aircraft finance, see generally Angelo Luigi Rosa, Harmonizing Risk and Religion: The Utility of Shari'a-Compliant Transaction Structuring in Commercial Aircraft Finance, 13 MiNN. J. Global. Trade 35 (2004).

4. The problem of uncertainty or risk in the structuring of Islamic commercial transactions, including insurance transactions, is discussed at length in Section II.E.

5. The example I have given involves a procedure known as tawarruq, where the asset sold and purchased is not only fungible but also resold immediately for its cash value. This is a somewhat controversial practice that is nonetheless gaining in popularity and is commonly practiced by Islamic banks on the Arabian peninsula. See Mahmoud El-Gamal, Limits and Dangers of Shari'a Arbitrage 9 (2005) available at http:// www.ruf.rice.edu/-elgamal/files/Arbitrage.pdf. Moghul and Ahmed describe a more conventional, orthodox murabaha structure, where the asset in question, jewelry, is used by the effective borrower rather than immediately resold. See Part III.B.1 infra.

6. See Frank E. Vogel \& Samuel L. Hayes III, Islamic Law and Finance: Religion, Risk, AND RetURn 198 (1998).

7. See id. at 144 .

8. See id. at 152; see also Ibrahim Warde, The Prophet and The Profits: Islamic Finance, Le Monde Diplomatique, Sep. 2001, at http://mondediplo.com/2001/09/09 islamicbanking. 
Some argue that legalistic acrobatics of this sort pose no obstacle to the development of Islamic finance, given literal adherence to the dictates of the shari'a. ${ }^{9}$ For example, Frank Vogel and Samuel Hayes, who wrote one of the most authoritative works on Islamic finance in the English language, seem entirely comfortable with the formalisms, fictions and artifices that dominate the practice. They even provide sophisticated techniques of their own that develop more fully the concepts discussed above. ${ }^{10}$ They assert that Islamic finance has not failed, given that Islamic commercial vehicles, such as the murabaha, are, on the narrowest technical grounds, based on profit-sharing that arises from the sale and purchase of assets. ${ }^{11}$ Underlying this is an assumption by Vogel and Hayes that Islamic commerce, as currently practiced, satisfies broad segments of Muslim society that are "socially and politically conservative, seeking individual piety and social mores built around traditional compliance with figh [Islamic law], and looks to social and political improvements mainly as a result of that." 12

This assumption is incorrect. Vogel and Hayes fundamentally misunderstand the cause for the recent explosive growth in Islamic finance and underestimate its current dilemma in attempting to expand further. Though the first Islamic banks came into existence little over three decades ago, Islamic finance has developed into a significant industry with assets in excess of $\$ 200$ billion dollars in Islamically-approved financial instruments, operating in over 70 nations and growing at an annual rate of over $20 \%$ per year. ${ }^{13}$ Yet at the root of such growth, frequently expressed as an article of faith by Muslim advocates of Islamic finance, is the perception that Islamic commercialism provides a fairer, more just, and more humane alternative to the alleged brutality of the global marketplace. ${ }^{14}$ Respect for traditional compliance with Islamic rules is not the touchstone; social justice is.

This perception of substantive fairness and social justice is so widespread and so deep that it is difficult to set forth enough authority in favor of it to underscore its centrality to modern Islamic finance. Three quite distinct Islamic figures who were central to the development of Islamic economics refer repeatedly to notions of social justice and fairness in their descriptions of Islamic economics, and in particular Islamic financial methods. ${ }^{15}$ These figures are, without exception, revolutionaries and by

9. See, e.g., Ibrahim Warde, Islamic Finance in the Global Economy (2000).

10. See Vogel \& Hayes, supra note 6 , at 235-87.

11. See id. at 137.

12. Id. at $27 \mathrm{n} .2$.

13. See WARDE, supra note 9 , at 1,75 . Malaysia, a nation with a highly developed Islamic financial system, has alone in excess of $\$ 23$ billion in Islamic assets, and reports growth in excess of $42 \%$ over the past decade. See Seelen Sakran, The Future of Islamic Banking, MALAYSIAN Business, Jan. 15, 2005, at 55.

14. See, e.g., Moghul \& Ahmed, supra 2, at 153.

15. See Mahmoud El-Gamal, "Interest" and the Paradox of Contemporary Islamic Law and Finance, 27 FORdHAM INT'L L.J. 108, 115, 120 (2003). Naturally, economics is a far broader discipline than finance, and the author does not suggest their equivalence. 
no means fit the model described by Vogel and Hayes of political and economic conservatives seeking modest social and political improvements through traditional adherence to the shari'a. ${ }^{16}$

The first of these, Muhammad Baqir as-Sadr, the thoughtful Shi'i Iraqi jurist who authored a highly influential tome on Islamic economics, as well as the seminal intellectual contribution to the creation of an interest-free bank in Islam, makes the point repeatedly in his writings. ${ }^{17}$ Sadr's goal was the establishment of an economic order entirely separate from the prevailing paradigms of capitalism and Marxism. ${ }^{18}$ The same can be said for the militant Sayyid Qutb, whose influence on radical Islamic movements remains vibrant. ${ }^{19}$ Many of Qutb's economic theories appear in a book entitled Social Justice in Islam. ${ }^{20}$ His assault on interest is particularly strident. He describes those who take usury as being without "conscience" or "ethics." 21 Finally, the highly influential Pakistani Islamist, Sayyed Abulala Maudoodi, describes taking interest in almost Marxist terms, suggesting that it increases maldistributions of wealth and perpetuates class struggle. ${ }^{22}$ Maudoodi saw the only solution as being the establishment of what he termed an "Islamic theo-democracy," hardly the words of a political conservative. ${ }^{23}$

These are by no means the sole contributors to the notion of fairness and social justice in the context of Islamic finance. Other later, deeply respected and much less revolutionary figures have said much the same.

However, Islamic notions of finance play an important role in Islamic economics, and inevitably, proponents of Islamic economics emphasize the fairness of both.

16. See Vogel \& HaYes, supra note 6 , at 26.

17. See Muhammad BaqIR AS-SAdr, lqtisaduna 60-65 (World Org. for Islamic Services trans., 1982) (1969) [hereinafter IQTISADUNA] (describing social justice as one of the cornerstones of Islamic economics); see also MUHAMMAD BAQIR AS-SADR, AL-BANK AL-LA RIBAWI FI 'L-ISLAM 6-7 (1973) [hereinafter AL-BANK] (referring to a form of distributive justice as being a principal objective of Islamic economics, and to the Islamic bank as being a key component of the economic system). Though a Shi'i jurist, Sadr's effect on the world of Islamic finance and Islamic economics in the broader Islamic world has been significant. Hamid Algar describes Sadr's works as "the most substantial treatment of social justice in Islam." Hamid Algar, Introduction to SAYrid QuTB, SOCIAl Justice IN Islam 12 (John B. Hardie \& Hamid Algar trans., 2000) (1949). See Chibli Mallat, The ReNewal of ISLAMic LAw 142-43 (1993).

18. See id. at 113-16; see generally IQTISADUNA, supra note 17.

19. See John L. Esposito, Unholy War: Terror in the Name of Islam 52 (2002) (describing Qutb as the "godfather" of contemporary Islamic radicalism); see also Bernard K. Freamon, Martyrdom, Suicide, and the Islamic Law of War, 27 FORDHAM INT'L L.J. 299, 348-50 (2003) (describing Qutb's influence). It is important to note that my comparison of these three different individuals is in one respect alone-they are all revolutionaries who may be fairly described as the forefathers of Islamic economics and Islamic finance. See El-Gamal, supra note 15, at 115.

20. Sayyid Qutb, Social Justice in Islam $101-42$ (John B. Hardie trans., 1953) (1949).

21. Id. at 107 .

22. See Sayyed Abulala Maudoodi, Economic Problem of Man and Its Islamic SoluTION 27-31 (Abdul Waheed Khan trans., Markaz Maktaba Jama'at-e-Islami 2d ed. 1955) (1947).

23. Sayyed Abulala Maudoodi, Al-Khilafa Wa-al Mul-k 13-21 (Ahmad Idris trans., Daar al-Qalam 1978). 
Muhammad Taqi Usmani, a former judge on the Shari'a Appellate Bench of the Pakistani Supreme Court, indicates much like Maudoodi that the charging of interest is partially responsible for the massive wealth disparities in capitalist societies. ${ }^{24}$ Umer Chapra, an economist at the Islamic Development Bank in Jeddah, Saudi Arabia, and one of the most wellknown and prolific advocates of Islamic finance in the Muslim world, makes notions of social justice central to his robust defense of Islamic finance. ${ }^{25}$ Muhammad Nejatullah Siddiqi, a professor of economics in Saudi Arabia, opens one of his most well-known books on Islamic economics with the sentence ". . . the main insight offered by Islamic economics is that ethics matters," 26 and another of his books opens with the sentence "[b]y prohibiting interest Islam has endeavoured to do away with a hideous form of tyranny and injustice prevalent in the human society." 27 Timur Kuran, an expert on and critic of Islamic economics, describes the prohibition of interest as "the most celebrated" injunction in Islamic economics by proponents of the discipline. ${ }^{28}$ Kuran indicates that these proponents ground the injunction on the principle of fairness. ${ }^{29}$ Ordinary Muslims are captivated by this perception and are shocked when, in seeking to obtain Islamic financing, they discover the ruse. ${ }^{30}$

Proponents of Islamic finance often repeat the same functional objectives of fairness and social justice, but do not employ appropriate methodological techniques to achieve these goals. An altogether different approach is used, one that claims its origins in the earliest foundations of Islamic jurisprudence and relies instead on a rigid formalism, in which public interest and judicial discretion play a very limited role. ${ }^{31}$ Given the

24. See Muhammad Taqi Usmani, An Introduction To Islamic Finance (1998). This is not a surprise given Usmani's links to the militant party led by Maudoodi. See ElGamal, supra note 15 , at $115 \mathrm{n} .19$. However, Usmani served in a high capacity in the Pakistani courts while Maudoodi was at one point sentenced to death in Pakistan, so it would be fair to describe Usmani as less militant and revolutionary.

25. See, e.g., M. Umer Chapra, Towards a Just Monetary System (1985).

26. Muhammad Nejatullah Siddiqi, Economics: An Islamic Approach, at iii (2001). Siddiqi's critique concerns economic affairs generally, not just merely finance. However, finance still plays an important role in his analysis. See, e.g., id. at 85-86.

27. See generally Muhammad Nejatullah SiddiQi, Banking without Interest, at $\mathrm{x}$ (1979).

28. Timur Kuran, On the Notion of Economic Justice in Contemporary Islamic Thought, 21 Int'l J. Middle E. Stud. 171, 174 (1989).

29. See id.

30. See Vogel \& Hayes, supra note 6 , at $26 \mathrm{n} .2$. In addition, the author has observed that many mosques and Muslim institutions in the United States refuse to deposit their funds in Islamic banks upon realizing the nature of the transactions into which they would be entering. More than one has called the author in anger and disgust, asking to be directed to "real" Islamic financial institutions. For a typical Muslim expression of this perception, as well as the frustrations associated with it, see Tarek El Diwany, Islamic Banking Isn't Islamic, June, 2003, http://www.islamic-finance.com/item 100_f. htm ("[T]he words 'profit-sharing' are to be heard constantly at all of the conferences fon Islamic finance]. Some of the scholars, if pressed, will talk about moving towards more satisfactory products . . . But then everyone goes home and works on another murabaha contract.").

31. Whether this type of logic-driven and rigid formalism is inherent to the entire history of Islamic jurisprudence is a matter much in dispute. See infra Part II.A. 
disparity between the functional ends and the formalist means employed to reach them, Islamic finance fails to meet the expectations set for it. ${ }^{32}$ Rather than offering any sort of alternative humanistic means of conducting commercial activity, the practice instead has devolved into an almost random patchwork of rules that are neither cohesive nor coherent. These inflexible and nondiscretionary rules are artificially forced into a paradigm to achieve ends for which they provide at best an awkward fit. As a result, they seem arbitrary and senseless, designed for no purpose and serving no function other than to complicate already elaborate commercial transactions. Social justice and avoidance of exploitation play no significant role. In Islamic finance, religion largely serves to obfuscate and complicate at some expense, while simultaneously and disingenuously asserting highly exaggerated claims of equity and social justice. ${ }^{33}$

This Article considers two issues. First, it seeks to provide a more precise description of the jurisprudential methodology employed in Islamic finance that has led to its failure. The dominant interpretive approach within contemporary Islamic jurisprudence, and Islamic finance in particular, shares many common features with the jurisprudential theories of Christopher Columbus Langdell. Both approaches are excessively rigid and dependent on formal exercises of logic, ${ }^{34}$ allowing the jurist or

32. This disparity between Langdellian means and functional ends was not lost on the original founders, and each made an attempt to compensate for this by accommodating public interest to some extent in their respective theories of economics. For example, Sadr indicates that contemporary jurists must engage in robust independent juristic reasoning to develop some of the rules of Islamic economics, clearly envisioning discretion and public interest as an implicit part of that process. See IQTISAdunA, supra note 17, at 364-90; see also infra Part IV.B.3. Qutb, at least in earlier editions of his work, Social Justice in Islam, references the importance of public interest in developing contemporary rules. See Hamid Algar, supra note 17, at 14-15. Finally, Maudoodi's notion of a "theodemocracy" is an attempt to combine Islamic norms with the demands of modern society. MAuDOODI, supra note 22. Only Sadr comes close to developing a methodology that incorporates these principles. See infra Part IV. Perhaps because they died when Islamic banking was either not in existence (in the case of Qutb) or in its infancy (in the cases of Sadr and Maudoodi), none of the three grasps the extent to which some of the most basic prohibitions they embrace, including the interest ban, render Islamic finance not simply inconvenient but also entirely impracticable in the modern era. As a result, the relative functional flexibility they espouse could not possibly succeed, unless it develops further to encompass those basic prohibitions, as this Article seeks to do in Part IV hereof.

33. Others made related observations on Islamic economics and finance, though not so much from a legal perspective. See, e.g., El-Gamal, supra note 15, at 135-36; OuIvier Roy, The Fallure of Political Islam, 132-46 (Carol Volk trans., 1994) (1992); Maxime Rodinson, Islam and Capitalism (Brian Pearce trans., 1973) (1966); Timur Kuran, Islam and Mammon: The Economic Predicaments of Islamism (2004). Kuran describes Islamic economics as "simplistic, incoherent and largely ir relevant to present economic challenges." See USC Today, Conversation With Timur Kuran, Dec. 18, 2006, http:// www.usc.edu/uscnews/stories/13215.html.

34. It is important to note that the failings of Islamic finance are not necessarily due to formalism per se, but to the type of logic-driven formalism characteristic of Langdellianism. For example, Justice Scalia unapologetically embraces a certain type of neoformalism based upon a strictly textual interpretation of statutes and the U.S. Constitution. See antonin Scalia, A Matter of Interpretation: Federal Courts and the Law 23-25 (1997). However, Scalia makes abundantly clear that his approach does not con- 
judge comparatively little interpretive control over the development of legal rules. $^{35}$

Second, it seeks to explain how Islamic principles might be used in a more salutary fashion in finance, avoiding unnecessarily the elaborate obfuscations and complications that serve no practical purpose while achieving some modicum of social justice in an Islamic setting. ${ }^{36}$ The more extreme forms of Legal Realism are not a workable solution in light of the nature of religious jurisprudence and the deep, historic importance of giving some role to Islamic doctrine and sacred text in developing Islam's legal rules. Rather than attempt a comprehensive alternative methodology, this Article seeks to outline principles necessary for any credible attempt at reform and will provide specific examples of how such principles might be applied. In so doing, it will become apparent that the changes necessary to

cern itself with the development of judge-made common law, such as that described by Langdell; rather, he suggests that the role of such judge-made law in the modern era of a democratically elected legislature should be severely curtailed. See id. at 3-14. Scalia is critical of legal education, as developed by Langdell, on the grounds that it creates a legal culture wherein there is an understanding that a judge plays a significant role in creating the law rather than simply interpreting a law created and implemented by others. See id. Therefore, Scalia's formalist and textualist approach presupposes a democratically elected legislature accountable to the general public that continually enacts laws as it sees fit. This approach is very different from the logic-driven quasi-scientific judge or jurist driven inquiry, which plagued Langdellianism in its time and plagues Islamic finance today.

35. No area of modern Islamic law, as currently applied, is immune to this same criticism, but the doctrinal failings are more obvious in Islamic finance. In alternative legal realms where the shari'a dominates the modern Islamic world, the concern of developing consistent legal tools sensitive to both social justice and modern contextual realities is less prominent. An excellent example is in the Islamic personal law, which is patently, unambiguously and without exception biased in favor of males within the traditional interpretive Islamic approaches. See, e.g., Weiss, The SPIRIt of IsLamic Law 188 (1998); Abdullahi A. An-Na'im, Islam and Human Rights: Beyond the Universality Debate, 94 Am. SOC'y INT'L L. 95, 97-100 (2000); NoEl J. Coulson, SuCCEsSION IN THE Muslim Family (1971); John L. Esposito, Women in Muslim Family Law 12-46 (2d ed. 2001); Donna E. Arzt, The Application of International Human Rights Law in Islamic States, 12 Hum. RTS. Q. 202, 208 (1990). In many Islamic nations in the world today, these rules generally apply, though exceptions exist. See, e.g., WEISs, supra note 35, at 188; René David \& John E. C. Brierley, Major Legal Systems in the World Today 438 (2d ed. 1978). However, the rigorous and extensive demands of the modern commercial marketplace that so shape Islamic doctrine in the area of finance play a less direct role in the development of personal law. See generally EsPosito, supra note 35. Thus, rather than conform to changed circumstances through artifice, jurists instead continue to apply personal law as it has always been applied. See id.

36. The author does not suggest that any form of social justice or fairness would satisfy the Muslim demand for a unique brand of finance. Naturally, those Muslims attracted to a concept such as Islamic finance take Islamic doctrine very seriously and would want any financial institution in which they invest to have a uniquely Islamic character. See id. at 101-2 (indicating that the desire to retain a distinct cultural identity drives much of Islamic economics); see also infra Part IV.A. Nevertheless, though identity politics play a role in developing a unique form of finance understood to be "Islamic," social and economic justice play an equally important, if not more important, role. Moreover, the author's recommendations in Part IV do not call for the elimination of culturally distinct Islamic financial institutions, but rather their reexamination in a way that would permit them to serve the social justice and fairness goals that Muslims seek and that proponents of Islamic finance advertise. 
develop an interpretive system, which will achieve the objectives of Islamic finance, are not as vast as might be imagined.

This Article illustrates its two central themes through an admittedly contentious comparison ${ }^{37}$ of the jurisprudential theories of Langdell and Muhammad Ibn Idris al-Shafi'i, the person credited by the dominant contemporary proponents of Islamic finance as responsible for systematizing the Islamic jurisprudence they use. Their respective jurisprudential interpretive systems, which the author shall call "modalities," are remarkably similar, both in terms of methodology and the consequences flowing from the application thereof. The author accepts Sherman Jackson's description of the American jurisprudential tradition as being "uniquely and abundantly rich in analytical tools and methods for inquiring into the nature, function, problems and possibilities of law." 38 The use of these tools, and the application of this comparative approach, provides useful insights for the American legal scholar on the basic and essential flaws in the dominant Langdellian interpretive trends that inhere to modern Islamic jurisprudence. As Professor Fletcher notes, these tools suggest solutions to seemingly intractable legal problems that might not otherwise be apparent. $^{39}$

Part I of this Article discusses the basic jurisprudential theories of Christopher Columbus Langdell, and then describes the reasons that

37. Despite the similarities in their respective approaches, the author has found only one other comparison of Shafi'i to Christopher Columbus Langdell, but this effort shows substantial limitations and is largely incomplete. See Amr A. Shalakany, The Analytics of the Social in Private Law Theory: A Comparative Study $142-59$ (1990) (unpublished Ph.D. dissertation, Harvard University) (on file with UMI's Dissertation Abstracts database). For example, Shalakany does not assign nearly the same fundamental importance to hadith in Shafi'i's jurisprudential system that this Article does, a puzzling omission given the importance of the hadith to Shafi'i himself. See id.; see also WAEL B. Hallaq, A History of Islamic Legal Theories 29 (1997) (remarking that, as compared to the discussions on hadith, "[n]early everything else [in Shafi'i's seminal work, AlRisala,] seems tangential"). Moreover, Shalakany tends to regard Islamic analogical reasoning, or qiyas, as somehow deductive in nature, similar to the deductive logic that Langdell employed to derive his rules from fundamental principles. See Shalakany, supra note 37, at 149-50. This Article takes almost an opposite approach, arguing that qiyas expands the specific hadith into Langdellian fundamental principles, and the type of demonstrable, Cartesian deduction insisted upon by Langdell did not exist in the Islamic context. Shalakany's comparison is limited in other ways as well. For example, he properly shows how both Langdell and Shafi'i created formal systems of law based on logic. However, he fails to contrast the systems in any methodological level of detail, both in deriving the proper cases and in expanding those cases into fundamental principles or fundamental rules from which all law would be developed. See id. Finally and most importantly, Shalakany does not, and given the lack of methodological detail could not, provide any contrast on the development of particular legal rules under the respective systems, nor does he, nor could he, compare the resulting failures of Langdellianism in the two contexts. To be fair to Shalakany, these were not his aims, as his very interesting and thorough dissertation fundamentally concerns the development of legal consciousness in the United States and Egypt, not the failures of the respective interpretive systems. See id. at 108-09.

38. Sherman A. Jackson, Fiction and Formalism: Toward a Functional Analysis of Usul al-Figh, in Studies in Islamic Legal. TheOry 177, 180 (Bernard G. Weiss ed., 2002).

39. See George P. Fletcher, Comparative Law as a Subversive Discipline, 46 AM. J. CoMP. L. 683, 695.97 (1999). 
Langdellianism ultimately fell from favor. Part II describes the Langdellian formalist modalities operating in Islamic finance allegedly developed by Shafi' $i, 40$ and then compares them to Langdellianism in terms of methodological approach. Specific examples relating to commerce are also provided in Part II to demonstrate how the Islamic Langdellian modalities function in Islamic finance. Part III outlines the principal rules governing contemporary Islamic finance through application of the Langdellian modalities, and then discusses how the existence of these financial rules results in the establishment of a bizarre and highly artificial construct that fails to address the social justice concerns central to the creation of Islamic banking and finance. Part IV discusses the principles that any alternative approach must follow to be faithful to the Islamic tradition and capable of achieving the central ontological objective of fairness in a commercially practicable manner.

\section{The Rise and Fall of Langdellian Legal Orthodoxy}

\section{A. Langdellian Methodology and Attendant Implications}

Christopher Columbus Langdell has been widely credited as the creator of the classical and orthodox theory of American jurisprudence. ${ }^{41}$ The basic thesis of Langdellianism is that law is a science, akin to the natural sciences, and that the relevant data set for the science of law are cases. ${ }^{42}$ From proper selection of the specimen cases, ${ }^{43}$ the legal scientist could derive the few, general fundamental legal principles that exist through inductive reasoning. ${ }^{44}$

The legal principles so derived functioned as the constituent ontological units within the construct. ${ }^{45}$ From them, through the rigorous and almost Cartesian application of logic and deductive reasoning, a series of clear specific rules would be derived that would govern any given case. ${ }^{46}$ The specific rules themselves were formalistic in conception, meaning that they were framed in a manner that made their application uncontroversial when applied to stipulated facts. ${ }^{47}$ The rules would then be the bases of

40. Unfortunately, although references to Shi'ism and Shi'i scholars, such as Muhammad Baqir al-Sadr, appear in this Article, Shi'i Islamic jurisprudence generally lies beyond its purview.

41. See, e.g., Grant Gilmore, The Ages of American law 42 (1977); Thomas C. Grey, Langdell's Orthodoxy, 45 U. Pitt. L. Rev. 1, 2 (1983); Pierre Schlag, Law and Phrenology, 110 HaRv. L. Rev. 877, 896 (1997).

42. See Gilmore, supra note 41 , at 42 .

43. Langdell asserted that the vast majority cases would not be worthy of study and might even prove "worse than useless." C.C. Langdell, Preface to the First Edition of A Selection of Cases on the Law of Contracts, at viii-ix (2d ed., Boston, Little, Brown \& Co. 1879). However, the fundamental principles that exist in the law could be discovered from studying the properly selected cases. See id. at viii-ix. Interestingly, however, Langdell never specified the means by which these proper cases could be identified.

44. See Stephen M. Feldman, From Premodern to Modern American Jurisprudence: The Onset of Positivism, 50 VAND. L. Rev. 1387, 1428 (1997).

45. See Schlag, supra note 41 , at 898 .

46. See Feldman, supra note 44, at 1428 ; see also Grey, supra note 41 , at 16-21.

47. See id. at 11 . 
decision-making in future cases. ${ }^{48}$

Three important consequences flow from the Langdellian jurisprudential modalities that resonate in the Islamic context. First, the modalities possess an inherent disdain for any notion of judicial discretion. They suppose that capable judges can deduce the applicable formal rule from the established principles in an uncontroversial manner. ${ }^{49}$ To the Langdellians, the notion that a judge would have any discretion in the deductive application of the rule would be abhorrent, as it would render the law an unscientific discipline. ${ }^{50}$

Second, the Langdellian modalities do not consider public welfare or public interest when rule-making for precisely the same reason. Langdell famously remarked that though the "mailbox rule," whereby an acceptance to a contract offer is deemed given on the date it is placed in the mailbox, might be more in the public interest, this fact was "irrelevant" because Langdellian logic made it impossible for a contract to exist before acceptance was communicated to the offeror. ${ }^{51}$ This position drew the criticism of Holmes, who famously retorted that the life of the law was not logic, but experience. $^{52}$

Finally, Langdellianism is largely impervious to broader social and economic developments. Fixed, immutable, and abstract principles simply cannot form the ontological units of a jurisprudential modality that would admit extensive social change. ${ }^{53}$ Langdellianism was designed to "discover" rules that admitted no possibility of evolution or development, and consequently could not keep pace with rapidly changing social, political and economic circumstances. 54

\section{B. The Failures of Langdellianism in the Modern Era}

There are four principal reasons that the Langdellian modality ultimately "crumbled," to use Gilmore's phrase, replaced by jurisprudential theories that relied less on pure logic, and more on discretion and experience, to develop and hone legal rules. ${ }^{55}$ First, the few fundamental principles and doctrines upon which the Langdellians placed so much reliance failed to materialize, as they were under constant revision and supple-

48. See id. at 20-21. There was a circularity to the reasoning, as cases provided the bases upon which the principles were induced and rules derived, but the rules also provided the bases upon which cases were to be decided. For an analysis of this circularity and the potential means by which it might be addressed, see id. at 20-24.

49. See id. at 11-12 (describing the system as "doubly formal" as a result).

50. See Gilmore, supra note 41 , at $42-43$.

51. C.C. Langdell, a Summary of the Law of Contracts 20-21 (2d ed. 1880).

52. See Oliver Wendell Holmes, Book Notices, 14 Am. L. Rev. 233, 234 (1880) (reviewing C.C. Langdell, A Selection of Cases on the law of Contracts (1879)).

53. See Gllmore, supra note 41, at 42-43. One commentator posits a potential means of development whereby new principles are "discovered" from existing case law and rules derived, but even he admits that such a process is inherently slow and strains at the foundational elements of the Langdellian jurisprudential modality. Grey, supra note 41 , at 31-33.

54. GILMORE, supra note 41 , at 43 .

55. Id. at 68 . 
ment. ${ }^{56}$ Secondly, judges faced with difficult cases often found two conflicting principles equally applicable. Cardozo went so far as to suggest that discretion was inherent in the judicial enterprise. ${ }^{57}$ This position was radical for its time. ${ }^{58}$

Moreover, considerations of public policy or justice were never suppressed, as judges or juries would simply neglect to apply them, finding one way or another to reach the result that seemed more just or practical. ${ }^{59}$ Finally, Langdellianism failed to keep pace with rapid social change in the beginning of the century due to its insistence on timeless principles. It became, to paraphrase Langdell himself, largely "irrelevant" as a swiftly changing polity required a new legal architecture and jurisprudential modality to develop rules more consonant with the reality in which modern actors tended to find themselves. ${ }^{60}$ The notion that sixteenth century legal decisions would continue to govern life in the post-industrial world could simply not be sustained.

\section{Langdellian Modalities in the Islamic Experience}

\section{A. Historical Qualification}

Islamic jurists, like American judges purporting to apply common law many centuries old, are not historians. They often work at cross-purposes to history, relying on highly stylized accounts that are, at best, simplistic and reductive and, at worst, inaccurate, to legitimize the jurisprudence on which they rely. However, these narratives are ingrained in the legal culture and serve as the engine of jurisprudential development.

There can be no doubt that contemporary traditionalist Islamic scholars, including those that operate in the realm of Islamic finance, adhere to what they consider the solely authentic brand of shari'a with its origins in the dawn of Islam. ${ }^{61}$ These scholars also overwhelmingly credit Shafi'i

56. For a contemporaneous critique of precisely this phenomenon, see Thurman $W$ Arnold, Institute Priests and Yale Observers-A Reply to Dean Goodrich, 84 U. PA. L. REV. 811, 820-821 (1936).

57. See Benjamin N. Cardozo, The Nature of the Judicial Process 166-67 (1946).

58. See GiLmore, supra note 41 , at 77 .

59. See Grey, supra note 41 , at 45.

60. See id. at 39 .

61. See Mohammad Taqi Usmani, An Approach to The Qur'anic Sciences 433-34 (Mohammad Swaleh Siddiqui trans., Rafiq Abdur Rehman ed., 2000) (describing rules derived under the Langdellian modalities, including those of interest, as having been established and agreed upon for over 1400 years, thereby dating it as being developed in Muhammad's time). Usmani has served on the Pakistani Bench and on the boards of a number of Islamic banks. See Muhammad Abu ZaHra, Usul Al-FiQh 8-12 (1969); see also Badran Abu al-Aynayn Badran, Usul Al-FIQH 5-12 (1965) (indicating that the modalities' origins principally lie in the period immediately following Muhammad's death). Badran and Abu Zahra have produced highly influential works on Islamic jurisprudential methodologies. See Mohammad Hashim Kamali, Principles of Islamic JurispruDENCE, at xvi (2003) (using Abu Zahra and Badran as principal references on the modalities used to derive the shari'a). In addition, the author has heard frequent references in several Iraqi law schools to Abu Zahra and Badran as two of the most authoritative voices on Sunni Islamic modalities in the modern world. 
with development of the methodology they use to derive the shari'a. ${ }^{62}$ Therefore, most would not simply credit Shafi'i as the founder of Islamic jurisprudence but would go further and indicate that Shafi'i did not found the jurisprudence so much as set down in writing (dawwana) a modality that existed from Islam's earliest days. This distinction consecrated the modality as an elemental part of the Islamic faith rather than the ex post interpretations of jurists, such as Shafi'i, who lived two or more centuries after Muhammad's death. ${ }^{63}$

More reform-minded Muslims would not agree with this idea of a sacred jurisprudence, as significant evolution of Islamic doctrine requires reexamination of the Islamic legend concerning shari'a development. ${ }^{64}$ Moreover, his historical account is simplistic and almost certainly inaccurate in many respects. Shafi'i's role in developing the jurisprudence is one area of contention. ${ }^{65}$ Another would be the extent to which formalist rigid-

62. See, e.g., ABU ZaHRA, supra note 61, at 12-14 (1969); BAdRAN, supra note 61, at 11-12; M. Cherif Bassiouni \& Gamal M. Badr, The Shari'ah: Sources, Interpretation, and Rule-Making, I UCLA J. IsLAMIC \& NEAR E. L. 135, 136-37 (describing, in admirable detail, the modern understanding of Islamic jurisprudence and methodologies used to derive it; crediting Shafi'i with systematizing this dominant methodology; and indicating that Shafi'i is commonly considered the founder of Islamic jurisprudence)

63. See BADRAN, supra note 61, at 11-12; ("And Shafi'i was faced with great juristic riches from the Companions and Successors to the Apostle of God [Muhammad] and thus we cannot say before these great riches anything other than that Shafi'i set down in writing the bases that the riches focus upon.") (translated by author); see also ABU ZAHRA, supra note 61 , at 12 (using the same verb, dawanna, to describe Shafi'i's achievement); Bassiouni \& Badr, supra note 62, at 136. Cf. KAMALI, supra note 61, at 4-6 (arguing that most Islamic methodological principles employed today largely predate Shafi'i, but nonetheless crediting him with founding the modality).

64. Abdullahi An-Na'im has made the point repeatedly in his writings that the shari'a is not an inherently divine code of conduct, but rather a fundamentally normative rather than legal code with roots in the divine, ultimately interpreted and applied by humans throughout history and consequently subject to manipulation and error. See, e.g., An-Na'im, supra note 35, at 97 ("While Muslims tend to ascribe divine authority to historical formulations of shari'a by jurists of the eighth and ninth centuries, it is clear that the precise content of that normative system has always been, and will continue to be, the product of human understanding in specific historical context"); ABDULLAHI Ahmed An-Na'im, Toward an lslamic Reformation: Civil Liberties, Human Rights, and INTERNATIONAL LAW 11-33 (1990). An- $\mathrm{Na}$ 'im indicates that unless Muslims dissociate the divine origin of the shari'a from the continuing human efforts to interpret it, Islam cannot play a positive role in the lives of Muslims. See An-Na'im, supra note 35, at 97. This is emphatically true in the case of Islamic finance.

65. Much scholarship, including the work of the most respected and influential Orientalists of the last century, emphasizes the ultimate influence of Shafi'i and dubs him the father of Islamic jurisprudence. JOSEPH SCHACHT, Origins OF MuHammadan Jurisprudence 11 (1950); Noel J. Coulson, A History of Islamic Law 59 (1964); Ignaz Goldziher, Introduction to Islamic Theology and LaW 21 (Hamori trans., 1981). Some recent scholars, however, and most prominently Wael Hallaq, indicate that this is largely historical fiction, and that Shafi'i had at best a minor role in the development of Islamic jurisprudence. See generally Wael Hallaq, Was Al-Shafi'i the Master Architect of Islamic Jurisprudence?, 25 INT'L J. OF MIDDLE E. STUD. 587 (1993). Others interpret Shafi'i's work differently, with Jackson considering him to be an anti-formalist (and an Arabist bigot) and another commentator insisting that he never intended to create a legal system with four identifiable sources of law. Jackson, supra note 38, at 187-91; Joseph E. Lowry, Does Shafi'i Have a Theory of Four Sources of Law?, in Studies IN ISLAMIC LEGAL THEORY 23-50 (Bernard G. Weiss ed., 2002). 
ity is truly faithful to classical Islamic interpretive theory. M. Cherif Bassiouni, a renowned expert on international criminal law, has indicated that classical Islamic criminal law was by its nature "policy oriented", even if in the contemporary era it is often applied in a "rigid and repressive" fashion. ${ }^{66}$ Mohammad Fadel and Sherman Jackson have been in the forefront of work concerning the development of classical Islamic law that suggests that it was far more flexible and discretionary than once believed. 67

Nevertheless, to the extent that particular modern Islamic interpretive modalities rely on ahistorical legends to sustain them, they are little different from the historical myths common in the United States. Among such American myths are the dubious historical propositions that seminal Supreme Court cases fundamental to American legal culture, such as Marbury v. Madison and Lochner v. New York, respectively stand for the establishment of judicial review and as a cautionary tale about the dangers of judicial overreaching on the basis of a fashionable social or economic theory. ${ }^{68}$ The work undertaken to uncover these legends in the Islamic and American contexts is, without question, worthy and commendable for any variety of reasons, but for purposes of this Article, irrelevant.

The author instead elects to engage the stylized historical narrative of Islamic jurisprudential history on its own terms, as it ultimately controls the hermeneutic and points the way towards enactment of necessary, organic and workable adjustments to the shari'a. Therefore, the author emphasizes that the narrative related herein is a reconstruction of Shafi'i, presupposing the role that Islamic finance proponents give him as setting down in writing their modality, and describing his views within the constraints of those assumptions. The description is not, by any means, intended to be a historically faithful rendition of this controversial figure,

66. M. Cherif Bassiouni, Sources of Islamic Law and the Protection of Human Rights in the Islamic Criminal Justice System, in IsLamiC Criminal Justice System 5 (1982).

67. See, e.g., Mohammad Fadel, Istihsan is Nine-Tenths of the Law: The Puzzling Relationship of Usul to Furu' in the Maliki Madhhab, in STUdies IN ISLAMIC LAW AND SOCIETY 161-76 (Bernard G. Weiss ed., 2002); Jackson, supra note 38, at 180; MOHAMMAD FADEL, adjudication in the Mal.iki Madhab; A Study of Legal. Process in Medieval Islamic Law (1995); Sherman Jackson, Islamic LaW and the state: The Constitutional JurispruDENCE of Shihab al-Din al-QARafi (1996).

68. See Marbury v. Madison, 5 U.S. 137 (1803); see also Lochner v. New York, 198 U.S. 45 (1905); Michael W. McConnell, The Story of Marbury v. Madison: Making Defeat Look Like Victory, in Constitutional Law Stories 13-32 (Michael C. Dorf ed., 2004); David E. Bernstein, The Story of Lochner v. New York: Impediment to the Growth of the Regulatory State, in Constitutional Law Stories $325-58$ (Michael C. Dorf ed., 2004). Marbury is the more instructive example, given its centrality to American jurisprudence. Historical research seems to demonstrate that John Marshall is not the father of judicial review, and that Marbury did not intend to establish judicial review, a doctrine which was in its day uncontroversial and utterly unremarkable. See McConnell, supra note 68. Therefore, the narrative, told to every incoming law student and universally accepted as fact by the bar and bench alike, of a clever Chief Justice ruling in the face of a hostile President to expand judicial power considerably, appears to be without historical basis. See id. It perhaps was concocted at a later date by a legal culture eager to anchor this vitally important doctrine in early Supreme Court precedent through a compelling, if historically false, narrative. See id. Storytelling, it seems, is not unique to the Islamic context. 
or of the rich and multifaceted jurisprudence that developed in the classical era after him. ${ }^{69}$

\section{B. Shafi'i and the Formalist Modalities in the Methodology of Hadith Reporting}

Shafi'i's central thesis, developed in his seminal work, Al-Risala, and elsewhere, is that revelation is comprehensive, determinative, and complete. ${ }^{70}$ Revelation includes not only the Qur'an but also the hadith, or the specific utterances of Muhammad. ${ }^{71}$ This inclusion of the hadith in revelation adds considerable legal material to the corpus of the shari'a, given that the Qur'an has only approximately 200 verses with legal content unrelated to religious ritual, ${ }^{72}$ and few of these verses are well developed or well defined. For example, the Qur'an proscribes transactions involving the consumption of riba (illicit gain), while simultaneously permitting, and indeed encouraging, bai' (sale), without providing precise definitions to determine which of the principles applies in any particular situation. ${ }^{73}$ The Qur'an orders believers to honor their contracts ${ }^{74}$ but provides no supplementary doctrinal principles of contract by which a jurist might determine when a breach has taken place, what the appropriate remedies are and whether there is an exception to the general Qur'anic principle. The hadith, by contrast, are more numerous, specific, and contextual-in many ways, akin to cases in the Langdellian construct. ${ }^{75}$

Shafi'i not only includes the hadith but also makes clear that they never depart from the maxims of the Qur'an and only serve to clarify and expound upon it. ${ }^{76}$ Shafi'i doggedly holds to this position even when it

69. There are numerous, valuable historical works on the development of Islamic jurisprudence in the classical era. For a classical discussion, see, e.g., SCHACHT, supra note 65; Coulson, supra note 65; GoLDZIHER, supra note 65 . For a more recent discussion, see, e.g. Wael B. Hallad, A History of Islamic Legal Theories (1997) (hereinafter History]; Wael B. Hallaq, The Origins and Evolution of Islamic law (2005) [hereinafter ORIGINS]; Weiss, supra note 35 . The author makes reference to these from time to time, though the focus remains primarily on the contemporary orthodox historical legend typically endorsed by proponents of Islamic finance.

70. Muhammad Ibn Idris al-Shafi'l, Al-Risala 99 43-47 (Ahmad Muhammad Shakir ed., 1940) [hereinafter RISALA].

71. See id. TI 43-47, 225-27, 569-71.

72. See Roy Parviz Mottahedeh, Introduction to Muhammad BaqIR as-Sadr, Lessons in IsLAmic Jurisprudence 1-2 (Roy Parviz Mottahedeh trans., 2003).

73. See QUR'AN 2:275.

74. See id. $5: 1$.

75. For example, doctrinal principles have been derived from Muhammad telling a man to tie his camel so that it does not flee, or instructing merchants that forward sales should always be accompanied by necessary specifics. See infra notes 212,141 . Analogizing to an American judicial case can only be taken so far, as Muhammad, acting as God's Apostle, clearly had the authority to issue an advisory opinion, or to settle political questions.

76. See, e.g., RISALA, supra note 70, II $535-37$ (using Muhammad's practices as related by the hadith to supply the particulars for the pilgrimage to Mecca mandated by the Qur'an), 613-18 (using the pilgrimage, the rules of prayer and theft as examples of the hadith providing particulars, and in some cases exceptions, that are absent from the Qur'anic mandates). 
appears untenable. ${ }^{77}$ For example, the Prophetic hadith prescribe death by stoning as the punishment for zina (non-marital relations) for non-virgin women, ${ }^{78}$ a punishment that remains law in some Islamic countries to this day. ${ }^{79}$ However, this punishment lies in flat contradiction to the Qur'an, which prescribes one hundred lashes for any man or woman engaged in sexual relations outside of marriage. ${ }^{80}$ Shafi'i refuses to see this as a contradiction, and instead points to a different verse that describes the punishment for slave women for falling into shame ("atayna bil fahisha"), to be half that of free women, reasoning that the hadith established no contradiction, but merely created a third category, non-virgin women. ${ }^{81}$

Therefore, to Shafi'i, the hadith are absolutely central in Islamic jurisprudence to the creation of a legal architecture. ${ }^{82}$ They are the fundamental ontological units of the jurisprudential theory, which are in practice, if not in theory, superior even to the Qur'an's verses.

For revelation to be comprehensive, determinative, and complete, the hadith, though similar to case law at first blush, must serve a role in Shafi'i's analysis not unlike that of Langdell's fundamental principles. Shafi'i needed to take two crucially important steps to achieve this. First, Shafi'i required definitional parameters to determine which hadith were the proper ones to use. ${ }^{83}$ As Langdell faced casebooks from dozens of jurisdictions, some centuries old, Shafi'i faced an unmanageable number of hadith supposedly from Muhammad, his Companions, and revered Successors. ${ }^{84}$ Some form of discrimination and determination undoubtedly was necessary to develop a sustainable jurisprudential architecture. Langdell never precisely defined his parameters, other than to declare the vast majority of cases to be "worse than useless," but Shafi'i was much more careful in this respect. ${ }^{85}$ His approach, repeated throughout his works, is clear:

Every hadith related by a person of confidence, on the authority of a person of confidence, until [the chain] ends with the Prophet, is certain to be from the Prophet and we do not disregard the hadith of the Prophet under any circumstances unless another hadith from the Prophet contradicts it; if there is a contradiction and one abrogates the other, then we accept the abrogating over the abrogated. If there is no sign of abrogation, then we accept the more certain of the two narrations, and if they are both certain, then we look to

77. See generally id. $991010-40$.

78. See id. 9227.

79. See, e.g., Vanessa von Struensee, Stoning, Shari'a, and Human Rights Law in Nigeria, 11 WM. \& MARY J. WOMEN \& L. 405, 405-406 (2005).

80. See QUR'AN 24:2.

81. RISALA, supra note 70, \ 227 (translated by author).

82. This point seems to be a matter upon which even Islamic historians would agree in light of the emphasis given to it in the Risala. See, e.g., SснаCHт, supra note 65, at 12; HistoRY, supra note 69 , at 25 . To this day, proponents of Islamic finance, and Islamic scholars generally, invariably describe the Qur'an and the hadith as the two primary sources of legal rules under the shari'a. See, e.g., Muhammad Nejatullath Siddiqi, PartNership and Profit-Sharing in Islamic LaW 12 (1985); Abu Zahra, supra note 61, at 100.

83. See SCHACHT, supra note 65 , at $315-19$.

84. See OrIGINS, supra note 69 , at 70-71.

85. See SCHACHT, supra note 65 , at 315-19. 
which harmonizes best with the Qur'an and the remainder of the hadith. ${ }^{86}$

The most important element of Shafi'i's position on hadith can be gleaned from this quotation-they are to be derived almost exclusively through chains of reliable transmitters, known as an isnad. ${ }^{87}$ If the isnad appears sound, then the authenticity of the hadith can only be questioned in the event of a direct contradiction with another sound hadith ${ }^{88}$ Even if a contradiction exists, harmonization with the Qur'an may establish the authority and applicability of the hadith only when no other more determinist technique offers an adequate solution. 89

Thus, selection of the hadith, the cases from which the fundamental principles would be drawn, was originally neither based on compatibility with the Qur'an nor on the dictates of human discretion, opinion, or harmony with public policy or practice, but rather on a lengthy chain of supposedly reliable narrators over a span exceeding one hundred years. ${ }^{90}$ That this methodology is highly flawed is accepted quite widely beyond the world of Islamic theologians. 91 However, Shafi'i returns to this point repeatedly, insisting on the isnad as the premier means by which the authenticity of hadith could be ascertained and selected. ${ }^{92}$

\section{Shafi'i's Reductionist Interpretive Controls in the Emerging Formalist Modality}

Shafi'i's second step to transform the hadith from specific cases to fundamental principles derived from the need to adopt a jurisprudential tool that would enable extension of the hadith beyond their literal original terms. One possible solution would have been the adoption by qadis, or judges, of a largely juristic discretionary principle whenever gaps arose,

86. Muhammad ibn IDris Shafi't, Ikhtilaf Malik wa Shafi'i, in 8 Mawsu'at al-Imam alSHAFI'l AL-KitAB Al-UMm 513 (Abdul Muttalib ed., 2001) [hereinafter Ikhtilaf Malik] (translated by author).

87. Eventually this method resulted in 4,000-5,000 hadith being accepted as sound out of a possible half million reports. See Origins, supra note 69, at 107 . As with Langdell, the vast majority of "cases" turned out to be "worse than useless." Id. at 110 .

88. See SCHACHT, supra note 65 , at 12 .

89. See id.

90. An example of an isnad appearing in Shafi'i's works reads: "And Malik, [who has heard] from Zaid son of Aslam [who has heard] from Atta son of Yasar, [who has heard] from Bassir son of Sa'id, who reports that Abu Huraira heard the Apostle of God state ...." Ikhtilaf Malik, supra note 86 , at pt. 2 (translated by author).

91. See, e.g., Sснаснт, supra note 65 , at 4 ("It is generally conceded that . . the classical corpus contains a great many traditions that cannot possibly be authentic. All efforts to extract from this often self-contradictory mass an authentic core . . have failed."). See generally Ignaz Goldziher, 2 Muslim Studies [Muhammedanische Studien] 17-251 (C.R. Barber \& S.M. Stern trans., 1971); G. H. A. JuYnboll, Muslim tradition: Studies in Chronology, Provenance and Authorship of Early Hadith (1983). Even those who find the extreme skepticism of the earliest commentators toward the substance of the hadith unwarranted consider the science of hadith-gathering to have been highly suspect and prone to error, if not outright fabrication. See, e.g., Coulson, supra note 65, at 64-65, 70; History, supra note 69, at 3; ORIGINs, supra note 69, at 104.

92. See SснACHT, supra note 65 , at 12 (indicating that Shafi'i repeats this point with "tedious monotony"). 
causing a slow movement towards recognizable norms based on the Qur'an, hadith and the opinions of judges. Yet Shafi'i abhorred any such approach, and spoke particularly stridently against adoption of the doctrine of istihsan, or preference based on generally equitable principles. ${ }^{93}$

Shafi'i argues that istihsan is not based on revelation and consequently is invalid. ${ }^{94}$ Moreover, Shafi'i insists istihsan is entirely arbitrary, possibly resulting in different conclusions under the shari'a for the same problem in different locations at different times. ${ }^{95}$ To Shafi'i, this inconsistency in result must be, from a jurisprudential standpoint, entirely impossible. ${ }^{96}$ Shafi'i is a classic Langdellian in this instance, clinging tenaciously, and beyond the bounds of good sense, to the notion that law must be a science, and that there should be exactly one determinable outcome to any given juristic problem. Shafi'i's objections are deep-rooted and transcend policy considerations. He compares the application of istihsan to voicing delusions and engaging in sin and, at one point, goes so far as to describe istihsan as illicit pleasure (taladhudh). ${ }^{97}$ This is similar to the Langdellians' reaction to Cardozo's ideas on judicial discretion as a form of "hard-core pornography." 98

Shafi'i instead repeats his demand that all law be grounded in revelation, if not explicitly, then through dala'il, or signs, contained in revelation itself. ${ }^{99}$ He considers these signs akin to the stars and the moon, which themselves are signs that permit Muslims to determine the direction of Mecca and adhere to the Qur'anic command to pray towards Mecca when they are not in its vicinity. ${ }^{100}$ This forced metaphor serves only to reinforce Shafi'i's belief that law was driven by some form of quasi-scientific logic, and that observation and study of the signs would determine the proper answer to any legal question.

Shafi'i indicated that qiyas, or a form of reasoning that is largely, but not exclusively, analogical, was the sole means by which the signs might be discovered and the cases translated into broader fundamental principles. ${ }^{101}$ Qiyas is less rigorous than the strictly Cartesian logic instituted by Langdell, and, from a logician's point of view, it is no doubt extremely

93. Shafi'i devotes an entire treatise to this subject. See MuHAMmad IBN IDRIS SHafi'I, Kitab Ibtal al-Istihsan, in 9 Mawsu'AT AL-IMAM AL-SHAF'I AL-KITAB AL-UMM 57 (Abdul Muttalib ed., 2001) (hereinafter Kitab Ibtal). Literally, the term istihsan comes from the root hasana, meaning "to be good" or "to deem good." HaNS WeHR, ARABIC-ENGLish DictionARY 208 (J. M. Cowan ed., 4th ed. 1994). A prominent Hanafi jurist later described istihsan as "the request for mildness or facility [sahula] in rulings . . . and the leaving of what is difficult or unpleasant ['asr] for what is simple or pleasant [yusr], which is the basis of [our] religion." Muhammad IBN AHMAd SARAKhsi, 10 Kitab AL-Mabsut 145 (1993) (translated by author). 05.

94. See Kitab Ibtal, supra note 93, at 65-67, 76; see also RiSALA, supra note 70, 99 504-

95. See Kitab Ibtal, supra note 93 , at 75-76.

96. See id.

97. See id. at 76; see also Risal_a, supra note 70, 91464

98. Gilmore, supra note 41 , at 77.

99. See Risala, supra note 70, I 1456; see also Kitab Ibtal, supra note 93, at 71-73.

100. See Kitab Ibtal, supra note 93, at 71-73.

101. See Risala, supra note 70 , 11460. 
problematic. $^{102}$ In that sense, it seems an unusual choice by Shafi'i, who clearly preferred logic and certainty to discretion and potential variation. Yet he had little other choice because qiyas is as reductive a tool as can be imagined, while still fulfilling the ultimate purpose that Shafi'i desired-the transformation of the hadith from specific cases to fundamental principles, the central units upon which Islamic jurisprudence rests. Unlike Langdell, this methodology is not two steps-inductive reasoning of cases to a principle, then deduction from a principle to a formal rule-but rather one step whereby a specifically precise rule is extended by analogy to a broader rule that can be thought of as a fundamental principle, or at least a fundamental rule, given its breadth. ${ }^{103}$ Despite this small difference between Langdell and Shafi'i, there are remarkable similarities between their approaches.

Shafi'i and those following him make clear that qiyas includes, but is not limited to, pure analogical reasoning that is almost inductive in nature, whereby a jurist identifies a ratio legis, or 'illa, and then applies this 'illa in a comparable case. ${ }^{104}$ The classic example is the prohibition against all intoxicants based upon the Qur'anic prohibition against the consumption of alcohol. ${ }^{105}$ Shafi'i and his successors also subsumed certain forms of $a$ fortiori reasoning, better described as deductive, within the qiyas rubric. ${ }^{106}$ For example, consuming large quantities of an item was prohibited if consuming small quantities was forbidden. ${ }^{107}$ Shafi'i made clear his preference for the latter type of qiyas, given its firmer logical foundations. ${ }^{108}$

In light of the imprecision that can adhere to the purer forms of analogical reasoning, differing jurists could still reach different results in the application of qiyas. To further reduce the possibility of non-uniform application of the shari'a, Shafi'i introduced (or merely "set down in writing," as some traditionalists would have it) ${ }^{109}$ a second interpretive control known as ijma, or consensus. ${ }^{110}$

The basis for ijma under the current modalities is a hadith that the community of Muhammad "would never agree to go astray."111 Shafi'i, apparently unaware of this hadith, referred to two other hadith in which Muhammad suggests that a Muslim should hold fast to the believers. ${ }^{112}$ From this, Shafi'i reasoned in a rather strained fashion that if a Muslim is

102. See Wael B. Hallaq, Legal Reasoning in Islamic Law and the Common Law: Logic and Method, 34 Clev. Sr. L. Rev. 79, 85-86 (1985).

103. For purposes of clarity and consistency the author continues to use the term "fundamental principle," despite the fact that "fundamental rule" might be more apt in some contexts.

104. See Risala, supra note 70, 9594 (using the term ma'na rather than 'illa).

105. See, e.g., Hallaq, supra note 102, at 88-89; see also RisalA, supra note 70, 991394

1400 (using a separate example concerning hunting during the time of the pilgrimage).

106. See Risala, supra note 70, 91483.

107. See id.

108. See id. (describing this as the strongest type of qiyas).

109. See ABU ZAHRA, supra note 61, at $189-90$ (describing ijma as having been developed by Muhammad's closest and most revered companions) (translated by author).

110. See Risala, supra note 70, TII 1101, 1315.

111. ABU ZAHRA, supra note 61, at 190.

112. See RisalA, supra note 70, $191101,1315$. 
not to deviate from the community, then a fortiori the community must be free of error. ${ }^{13}$ Moreover, Shafi'i argued that the communal determination must be applied in perpetuity because otherwise, the effect of the ijma would always be to give the current generation of scholars the right to overrule their forebears, vanquishing the notion of absolute authority. ${ }^{114}$ In addition to resisting temporal constraints, Shafi'i devoted considerable energy to refuting the notion that there could be a local or limited Islamic ijma among a geographical region, or that ijma could apply to a supermajority of scholars, as opposed to strict unanimity of them. ${ }^{115}$

As would be the case with anyone analogizing scientific endeavor to deduction of legal rules, Shafi'i appeared obsessed with obtaining the single correct result and ensuring its uniform application over time and place. Therefore, Shafi'i's modality is like Langdell's and extraordinarily resistant to variation. For Langdell, the rules derived from such principles are deductive, straightforward, and not subject to serious future challenge, while Shafi'i not only raised hadith to the equivalent of commandments from God but also crystallized and canonized particular extensions of them through the doctrines of qiyas and ijma.

\section{Anti-formalism and the Langdellian Modality}

A full discussion of the dominant Langdellian modalities is impossible without discussing two anti-formalist tools dismissed by Shafi'i but nonetheless found in Islamic jurisprudence. ${ }^{116}$ Their influence over the development of jurisprudential principles is generally slight in the contemporary era but is significant enough to bear mention, particularly because they played a minor role in deriving the rules governing Islamic finance.

\section{Istihsan}

Istihsan, the target of Shafi'i's fiercest attacks, is the primary anti-formalist jurisprudential tool that still remains part of the dominant modality applied in modern Islamic finance. ${ }^{117}$ It was classically permitted only by

113. See id. 991105,1320 ("[A]nd thus it is not possible for the community in its entirety to be in error, on the meaning of the Qur'an, or the hadith or the application of qiyas") (translated by author).

114. See Ikhtilaf Malik, supra note 86, at 763.

115. See id. at 763-71.

116. This is not meant to suggest that other, lesser sources of Islamic law do not exist. Bassiouni and Badr do an admirable job of cataloging and describing all such sources. See Bassiouni \& Badr, supra note 62, at 138-159; see also Bassiouni, supra note 66 at 910. It suffices to say, however, that none of the sources other than those described in the text plays a major role in the development of Islamic jurisprudence in the world of contemporary Islamic finance.

117. Interestingly, the dominant modalities, to preserve the impression of a unified jurisprudence that has existed from Islam's birth, strive mightily to minimize the differences between early jurists, such as Shafi'i, who seems to regard istihsan as a moral failing, and the eponyms of the Hanafi and Maliki schools, the latter of whom indicated that istihsan is nine tenths of the law. For example, Kamali points out that even Shafi'i employed istihsan once, though it is hard to see how one casual and minor reference 
two of the four primary schools of thought in Sunni Islam, the Hanafi and Maliki. ${ }^{118}$ Istihsan is of secondary status, to be used only when the hadith offers no explicit solution, qiyas does not lend a satisfactory answer, and there is some necessity or reason for applying the alternative rule. ${ }^{119}$ For example, Islamic jurisprudence has derived a prohibition against certain extraneous stipulations in contracts, based on a series of hadith. ${ }^{120}$ However, some stipulations common in customary commercial practice are permitted by some jurists through the doctrine of istihsan. ${ }^{121}$ Therefore, the continued existence of istihsan may impose fewer interpretive controls in developing modern commercial rules but the effect is largely marginal.

\section{Istislah}

Istislah, or concern for the public interest, is a supplementary jurisprudential doctrine adopted by the Maliki and Hanbali schools of thought, and it bears remarkable resemblance to istihsan both in its purposes and its very narrow scope. ${ }^{122}$ It is used to guide the process of qiyas or to provide an answer that somehow harmonizes with or is near to, but not rigidly derived from, qiyas. ${ }^{123}$

\section{E. Demonstrations of Langdellianism: The Problems of Riba and Gharar in the Formalist Modalities}

'Abd al-Razzaq Sanhuri, the premier Arab jurist of the last century, was as influential to the establishment and subsequent development of the legal order in the post-colonial Middle East as Blackstone and Coke were to the development of the common law. ${ }^{124}$ Sanhuri contended that three doc-

could possibly negate Shafi'i's strident attacks on the doctrine contained in his more well-known works. See Kamal1, supra note 61 , at 344 . Abu Zahra posits that Shafi'i was not directing his attacks against istihsan, as the Hanafis understood it, so much as istislah, discussed infra Part II.D.2, which is what the Malikis really meant by istihsan. See ABU ZAHRA, supra note 61, at 258-60. In any event, Abu Zahra argues that the differences are not as great as they might seem. See id. at 271-72.

118. See, e.g., id. at 251; Kamal., supra note 61, at 332-34. The four classical schools of thought within the Sunni jurisprudential tradition are the Hanafis, Shafi'is, Hanbalis and Malikis. See Bassiouni \& Badr, supra note 62, at 161. Modern Islamic scholars tend not to divide themselves according to school of thought, and, in applying the Langdellian modalities, tend to minimize any differences that might have existed between the classical schools. See, e.g., supra note 117.

119. See ABu ZaHRA, supra note 61, at 251.

120. See 'Abd al-Razzaq Ahmad Sanhuri, 3 Masadir al-haqQ fl al-FiQh al-Islami: Dirasa muQARanaH bi-Al-FiQH al-Gharbi (The SOURCes of Truth in Islamic Jurispru. Dence: A Comparative Study With Western Jurisprudence] 172-73 (1967).

121. See id. at 173 .

122. See ABU ZaHRA, supra note 61 , at 260 (indicating that Malik's references to istihsan were primarily meant to cover istislah).

123. See id. at 281-83.

124. As any common lawyer in the early nineteenth century would naturally have a copy of Blackstone's Commentaries by his side, so any Arab lawyer working in most of the Arab countries of the Middle East would refer any legal question concerning interpretation of the civil code to Sanhuri's multi-volume Al-Wasit, which functions effectively as his commentaries on the Egyptian Civil Code. See 'AbD Al-RazzaQ Ahmad SANHURI, Al-Wasit fi SHARH al-QANUn Al-MAdANI Al-Jadid (1952). See, e.g., William M. 
trinal prohibitions in the shari'a, as interpreted under the dominant modalities, were particularly problematic in the development of Islamic commercial jurisprudence. These are (a) the prohibition of riba, or illegitimate gain, ${ }^{125}$ (b) the prohibition of gharar, or particular forms of risk, and (c) the prohibition of stipulations or multiple bargains in a single contract. Sanhuri argues that these are entirely divorced from that which commercial practice demands, ${ }^{126}$ leading one prominent English legal practitioner in the Arab world to remark, in furtherance of Sanhuri's claim, that "[i]n the modern commercial context, the shari'a is an embarrassment." 127

This section examines two of the three problematic principles laid out by Sanhuri, riba and gharar, as they constitute paradigmatic examples of the means by which formal fundamental principles are established under the dominant Langdellian modalities in modern Islamic finance. ${ }^{128}$

Ballantyne, Essays and Addresses on Arab Laws 79 (2000). Sanhuri drafted the civil codes of both Egypt and Iraq, and served as dean of the historically prestigious Cairo and Baghdad colleges of law. His civil code is the template of the civil codes of nearly every nation in the Middle East, excluding those governed entirely by the shari'a. See Abdullahi Ahmed An-Na'im, Globalization and Jurisprudence: An Islamic Law Perspective, 54 EMORY L.J. 25, 47 (2005).

125. For a fuller description of the controversies concerning the definition of the term riba, see infra Section II.E.1.

126. See SANHURI, supra note 120 , at 14 .

127. Ballantyne, supra note 124 , at 82 .

128. The Article does not discuss the third prohibition, stipulations and multiple bargains in contract, simply because the rather extensive discussion it requires would prove unnecessarily burdensome to the central theses the Article seeks to advance. The thesis is demonstrated well enough by the doctrinal prohibitions of riba and gharar. However, the example of stipulations is a fascinating one, as it demonstrates the extent to which modern Islamic financiers are forced to ignore the Langdellian modalities when their extensive and elaborate artifices cannot surmount them. According to Vogel and Hayes, modern Islamic finance rarely pays heed to the specific prohibitions against stipulations in contract (such as, for example, a requirement attending the purchase of a camel that the camel be transported to a particular location at the seller's expense), relying on a classical interpretation of Ibn Taymiyah that does not appear to prohibit stipulations, unless they contradict the contract or otherwise violate the shari'a. See VOGEL \& HAYES, supra note 6, at 101 (citing Sanhuri, who quotes Ibn Taymiyah); see also SANHURI, supra note 120 , at 167-68. Ibn Taymiyah belongs to the Hanbali school, which traditionally approves of a single stipulation in any agreement of sale, but no more. Ibn Qudamah, for example, indicates that Ibn Hanbal, the eponym of the Hanbali school, reports a hadith, also contained in two of the six works that constitute the classical corpus of hadith, which prohibits two stipulations in a sale, but that Ibn Hanbal rejects a separate hadith, nevertheless appearing in two of the six canonized texts as well, prohibiting even a single stipulation. See MuwaffaQ al-Din 'Abd Allah ibN Ahmad ibn Qudamah et al., 6 Al-MuGHNI 321-22 (1986). Ibn Taymiyya also rejects the latter hadith on the authority of his mentor, Ibn Hanbal. However, Ibn Taymiyya says absolutely nothing about the former restriction. IBN TaymiYah, 6 Al-FataWA al-kUbra 408 (1987); IBN TaYmiYya, NazARIYYAT AL-'AQD [OpINIONS ON THE LAW OF CONTRACT] 14-16 (1977). The irony is that despite their rigid insistence on the absolute authority of the eternal validity of the Prophetic hadith, the Langdellian proponents of Islamic finance are disregarding one, and possibly two, hadith with sound isnads per the writings of a single fourteenth century jurist, who provided no basis at all for doing so. 


\section{Contours of the Riba Proscription}

Riba as currently understood is possibly the most difficult of the commercial prohibitions contained in the shari'a to incorporate into modern commercial practice. The prohibition of riba derives from several verses of the Qur'an, the most prominent of which is verse 2:225, which reads:

Those who devour riba cannot rise . . [T] hat is because they say, bai' [sale] is like riba. But Allah has allowed bai' and forbidden riba. Those who, after receiving direction from their Lord, desist, shall be pardoned for the past; their case is for Allah (to judge); but those who repeat (the offense) are companions of the Fire: They will abide therein (forever). ${ }^{129}$

However, while the verse makes abundantly clear a vast conceptual difference between riba and bai', the contours of the terms themselves are almost entirely undefined. The term riba has been variously translated as "unjustified profit," "illicit gain," "usury" or, most broadly, "unlawful gain by way of excess or deferment," which effectively would mean interest. ${ }^{130}$ From this and other verses, it is also clear that riba was a practice known in Muhammad's lifetime (hence the reference to those who compare it favorably to bai'), that it potentially involves enormous profit, ${ }^{131}$ that it involves some form of exploitation that can be compared to theft, ${ }^{132}$ and that its opposite appears to be charity. ${ }^{133}$ The Qur'an provides little guidance beyond this.

The riba practice in Muhammad's time appears to have been a transaction between lender and borrower, whereby the lender agrees to delay repayment of a loan at the time of repayment in exchange for doubling of the value of the loan. This explains the Qur'anic reference to "doubling and redoubling" in verse $3: 130 .{ }^{134}$ This practice is commonly known as riba al-jahiliyya. Indeed, Ibn Abbas, Muhammad's cousin, reports a sound hadith that the only riba is riba al-jahiliyya. ${ }^{135}$ Yet a second hadith reads as follows:

Gold for gold, like for like, hand to hand and any excess is riba. Silver for silver, like for like, hand to hand and any excess is riba; grain for grain, like for like, hand to hand and any excess is riba; salt for salt, like for like, hand to hand and any excess is riba; barley for barley, like for like, hand to hand and any excess is riba; dates for dates, like for like, hand to hand, and any excess is riba. And if the kinds differ, then sell as you wish, so long as it is

129. QUR'AN 2:225 (translated by author)

130. See, e.g., Noel J. Coulson, Commercial Law in the Gulf States 100 (1984); Nabil A. Saleh, Unlawful Gain and Legitimate Profit in Islamic Law 13 (1986).

131. See QuR'AN 3:130 ("Oh ye who believe, do not devour riba, making it double and redouble...") (translated by author).

132. See id. 4:161 (promising a painful punishment for those who devour riba and those who devour the property of others falsely).

133. See id. 30:39 "And whatever you lay out as riba, so that it may increase in the property of men, it shall not increase with Allah; and whatever you give in charity, desiring Allah's pleasure, you shall get manifold.") (translated by author).

134. See Vogel \& Hayes, supra note 6, at 72-73; see also S.E. Rayner, The Theory of CONTRACTS IN Islamic Law 268-69 (1991), see also Sanhuri, supra note 120, at 241.

135. See id. at 222-23. 
hand to hand. 136

The two hadith on riba are not easily reconcilable, and Ibn Abbas, as well as a few like minded Companions, appear to have maintained the validity of his narrower definition of riba, though there are debatable reports that he abandoned his claim when confronted with the broader hadith. ${ }^{137}$ Yet these conflicting hadith are not to be ignored under the modalities, given the centrality of the hadith to the development of legal rules. As a result, Ibn Abbas' hadith was declared by juristic consensus to be in some way misunderstood, and riba al-jahiliyya is, in light of the language of the Ibn Abbas hadith, perhaps the strongest of several potential forms of riba, but other forms exist. ${ }^{138}$

The second hadith quoted above adds two categories of riba, one in which certain hand to hand, or simultaneous, transactions result in a material gain for one party, and one in which a transaction results in delayed receipt on the part of one party. ${ }^{139}$ The hadith only applies to six items, and even then, only to trade within any particular item when excess values are concerned. Yet the tool of qiyas as applied reductively within the modalities took this relatively narrow rule and broadened it into a fundamental principle of considerable breadth, forbidding trade of various kinds between items resembling those on the list unless the trade was simultaneous, or of equal value. ${ }^{140}$ Classically, and in keeping with the terms of the hadith, jurists obsessed primarily on the sales and trades prohibited by it, not whether it encompassed loans. ${ }^{141}$ However, Islamic finance has con-

136. SARAKHSI, supra note 93, at 110 (translated by author); SANHURI, supra note 120 , at 177 (translated by author). A similar version appears in the Risala as well. See RisalA, supra note $70,91518$.

137. See SANHURI, supra note 120, at 222, 226.

138. See id. at 224-27 for classical references suggesting this. The idea that the Ibn Abbas hadith is meant to suggest that riba al-jahiliyya is the strongest but not the exclusive form of riba is not altogether impossible reasoning, given an Arabic idiomatic peculiarity where the negation of the existence of all other types of an entity or style can merely be an emphasis on the strength of that entity or style. For example, Muhammad is known to have said that there is no youth except his son in law Ali, and no sword except Ali's sword. Clearly Muhammad knew of the existence of other youth and other swords, and the statement is meant more in praise of Ali's prowess than as a statement of exclusion. See Philip K. Hitti, History OF tHE ARABs 183 (1937) (translating this hadith as "no sword can match [Ali's] and no young warrior can compare with 'Alii'").

139. See VOGEL \& HAYES, supra note 6 , at 74 .

140. See id.

141. See, e.g., SANHURi, supra note 120, at 178-94. No consensus was ever reached on the parameters of the relevant prohibited trade classifications in classical jurisprudence once this hadith was expanded through qiyas. For example, jurists disagreed as to whether the hadith, when expanded to a fundamental principle, should classify items by weight and volume and prohibit delayed exchanges within each classification, as the Hanafis and Hanbalis believed, or whether the hadith should classify items as currency or preservable and non-preservable foodstuffs, as the Malikis maintained, or simply currency and foodstuffs, as the Shafi'i's maintained. See id. The inquiry is largely casuistic and irrelevant for the purposes of this Article. However, it should be noted that there is an exception to this rather broad restraint on trade based on a separate series of hadith that permit a practice known as salam, or advance purchase of commodities if accompanied by specific information and full advance payment. See MuHammad ibN Isma'il BUKHARI, 3 SAHIH AL-BUKHARI 35 (1990) ("The Messenger of Allah came to Madinah, and 
cluded that an ijma, based on this hadith, prohibits trades of not only gold and silver but also of all other forms of currency, unless hand to hand and without excess. ${ }^{142}$ Thus, riba has become synonymous in the modern era with interest of any kind on a loan, and jurists in Islamic finance routinely dismiss any alternative conclusion, based on the employment of alternative modalities, as "apologetic" or "defeatist."143 Since the modality admits no possibility for the community to be mistaken in reaching this ijma, the

found its inhabitants entering salam contracts in fruits for one, two, and three years. He said: 'Whoever enters into a salam contract, let him specify a known volume or weight, and a known term of deferment.' ") (translated by author); see also VOGEL \& HAYEs, supra note 6, at 74, 139; see also SANHURI, supra note 120, at 35, 190.

142. See Vogel \& HAYES, supra note 6 , at 77 ; see also SALEH, supra note 130 , at 48 . Classical references seem to support this conclusion to some extent. See, e.g., IBN QUDAMAH, supra note 128 , at 436 (declaring an ijma on the subject). Ibn Qudamah and the prominent Hanafi jurist, Sarakhsi, both also report a hadith that prohibits a loan with a benefit. See id.; see also SARAKHSI, supra note 93, at 35. The latter hadith, however, is of arguable validity given particular problems with the isnad. See VOGEL \& HAYES, supra note 6 , at 77 . In addition, it should be noted that loans were considered charitable acts in the early Islamic period, and the notion of a loan with a benefit would therefore probably be considered odious to Muslims in the classical period. See, e.g., IBN QUDAMAH, supra note 128, at 429-30 (discussing the ethereal rewards given to those who offer interest free loans to their fellow Muslims in need).

143. See, e.g., Mohammad Uzair, Impact of Interest Free Banking, $1 \mathrm{~J}$. IsLamic Banking \& FIN. 39, 40 (1984) ("By this time, there is a complete consensus of all . . schools ... and among Islamic economists that interest in all forms, of all kinds, and for all purposes is completely prohibited in Islam. Gone are the days when people were apologetic about Islam, and contended that the interest for commercial and business purposes, as presently charged by the banks, was not prohibited by Islam."); USMANI, supra note 24, at 111 (describing the position permitting some forms of interest as "defeatist"); CoUNCIL of Islamic Ideology, Government of Pakistan, Report of the Council of Islamic Ideology on the Elimination of Interest from the Economy, in CONSOLIDATED RECOMMENDATIONS ON THE ISLAMIC ECONOMIC SYSTEM 7 (1983) (indicating the presence of "complete unanimity among all schools of thought in Islam that the term riba stands for interest in all its types and forms"); AbDullah SaeEd, Islamic Banking and INTERESt 50 (describing this position as "dominant" and "the basis of Islamic banking theory as well as practice"); ChAPRA, supra note 25 , at 63 . This position has come under attack by some modern reformist-minded jurists using anti-formalist hermeneutical techniques. See, e.g., SANHURI, supra note 120, at 219-49; Chibli Mallat, The Debate on Riba and Interest in Twentieth Century Jurisprudence, in ISLAMIC LAw AND FINANCE 69, 8--81 (Chibli Mallat ed., 1988). This is discussed further in Part IV, but the point here is that anti-formalist interpretive modalities are not entirely extinct. However, the dominance of the Langdellian position and the marginalization of the various anti-formalist modalities of modern reformers should not be understated. The Egyptian Constitutional Court, when asked to rule on the issue of whether the Civil Code's provision of interest violated the shari'a, adopted neither the riba interpretations of Sanhuri, the drafter of the Civil Code, nor of Rashid Ridha and Muhammad Abdu, both respected reformist Islamic scholars working at one of the most prestigious Islamic centers of learning in the modern world. Instead, the Court accepted the notion that interest on loans was indeed riba and therefore banned by the shari'a, but then contended that the constitutional amendment that demanded all laws conform to the shari'a was not intended to apply in any meaningful way to legislation enacted prior to its adoption. See Rector of the Azhar University v. President of the Republic, Judicial Year No. 1, Case No. 20 (Sup. Const. Ct. 1985) (Egypt), reprinted in W. M. Ballantyne, Supreme Constitutional Court (Egypt)-Shari'a and Riba, 1 ARAB L.Q. 100 (1985). That the Court preferred this type of legalistic nonsense to the adoption of a coherent anti-formalist position on riba speaks volumes about the virtually exclusive control that the Langdellian modalities have in deriving the substance of the shari'a. 
derived rule is unassailable and will haunt Islamic finance for as long as it continues to cling to its Langdellian ways.

\section{Gharar}

Unlike riba, whose foundational elements are contained within the Qur'an, the jurisprudential doctrine of gharar, or risk, is nowhere mentioned in the Qur'an, and the verses from which it is derived form an attenuated justification for it through the prohibition of maysar, or games of chance. ${ }^{144}$ The most often cited verses are 5:90-91, ${ }^{145}$ which read as follows:

O you who believe! Intoxicants and maysar, sacrifices for idols and divination by arrows are an abomination, the work of Satan, so avoid them so that you may be successful.

By means of intoxicants and maysar Satan only wants to sow enmity and hatred among you and take you from the remembrance of Allah and prayer, so will you not abstain? ${ }^{146}$

The juxtaposition of maysar with alcohol, activities of divination, throwing arrows, and sowing enmity and hatred and creating some distance between the believers and the worship of God, does not indicate that maysar was meant to address more than standard forms of gambling. That the Langdellian modalities would expand this prohibition to encompass significant levels of risk in modern financial and commercial transactions seems astonishing and entirely incongruent with the verse.

However, the hadith on the subject do forbid high levels of uncertainty in commercial transactions despite the incongruity. A variety of hadith forbid the sale of unripe fruit on a tree, the sperm of a stallion, the fetus of a camel, grapes until they are black, or grain until it is strong. ${ }^{147}$ Applying qiyas to these and related hadith, the Langdellian modalities have derived a series of rules concerning gharar that stringently limit levels of uncertainty in contemporary commercial transactions. ${ }^{148}$ All of these have been ratified and consecrated as immutable rules under the doctrine of ijma. ${ }^{149}$

The two central fundamental principles involving gharar are a prohibition against the sale of an item not currently in existence, ${ }^{150}$ and a ban on

144. See Saleh, supra note 130 , at 85 .

145. See, e.g., VOGEL \& HAYES, supra note 6, at 64; SAlEH, supra note 130, at 62 .

146. QUR'AN 5:90-91 (translated by author). A similar verse appears in 2:219, where maysar and intoxicants are said to have both benefit and sin, but that the sin exceeds the benefit. See id. 2:219.

147. See Ibn Rushd, 2 The Distinguished Jurist's Primer [Bidayat Al-Mujtahid] 17980 (Imran Ahsan Khan Nyazee trans., 1996). This is another example of an area in which the doctrine of istihsan has provided marginal levels of interpretive flexibility in the classical era. For example, some jurists recognize the doctrine permitting the sale of fruit on a branch so long as it is cut imminently and ripens fully after its cutting. See SARAKHSI, supra note 93, at 197.

148. See Vogel \& HaYes, supra note 6, at 87-95.

149. See id.

150. See, e.g., SANHURI, supra note 120 , at 31 ("[A]nd thus we find that there is an ijma among the schools of thought that if an object is not at all in existence at the time of contracting, then the contract is void.") (translated by author); VOGEL \& HAYES, supra 
all significant uncertainties in a contract, such as any uncertainty over cost or duration. ${ }^{151}$ The effect of these prohibitions, and particularly the ban on uncertainties, is commercially devastating.

There are two exceptions to the prohibition of gharar, one developed as a result of a contradictory hadith, and the other derived from an application of istihsan in the classical era and extended by modern Islamic finance. ${ }^{152}$ As to the first exception, advance purchases, known as salam, were permitted by Prophetic hadith ${ }^{153}$ so long as they did not pertain to particular objects and were generic or abstract sales. ${ }^{154}$ The delivery of cash for the purchase had to be immediate. A bilateral executory contract, where the seller agreed to purchase at a later date and the buyer agreed to buy at that date, was invalid. ${ }^{155}$ The second exception related to a concept known as istisna, pursuant to which parties contract for the manufacture of particular goods not in existence at the time of contract formation. ${ }^{156}$ The doctrine exists, and has existed classically, through the doctrine of istihsan, making it a very limited exception to the prohibition against sales of nonexistent objects. ${ }^{157}$

note 6 , at 91 . This is reflected in classical texts as well. See, e.g., IBN Rushd, supra note 147 , at 124 ("[T] hus all of the jurists have reached an ijma that [the sale of fruit prior to its appearance] is forbidden because it is the sale of an item not created.") (translated by author).

151. See SANHURI, supra note 120 , at 49 . Thus, a price pegged to a varying index or a lease contract that imposes largely unknown liabilities on a lessee falls well within the bounds of prohibited gharar in Islamic finance. See VOGEL \& HAYES, supra note 6, at 93, 144. Classical jurists, for their part, tended to classify gharar as being either large or small, with scholars agreeing generally that the large form was prohibited and the smaller form permitted. See, e.g., IBN RuSHD, supra note 147, at 175-77 (comparing schools of law with respect to great and small forms of gharar); $f$. SANHURI, supra note 120 , at 47 (quoting other classical jurists who include a third form, moderate gharar, about which there is disagreement as to its permissibility). There was considerable disagreement about what constitutes large gharar and small gharar. See IBN RUSHD, supra note 147 , at $175-81$. However, the prohibited large form generally inheres in contracts of sale or other profit-based contracts (as opposed to gratuitous contracts or contracts of marriage) when it has a large effect on the contract. See SANHURI, supra note 120 , at 49. Thus, jurists disagreed on whether the non-presence of an existing object, fully described at the time of sale, would create a form of gharar as large or small, with some arguing that the non-presence has no effect on the contract, and others, such as Shafi'i, insisting that it does. See IBN Rushd, supra note 147, at 177-78.

152. See Vogel \& HaYes, supra note 6 , at 89 .

153. See supra note 141.

154. See Vogel \& HaYes, supra note 6 , at 89 . Thus, for example, the immediate purchase of a certain number of bushels of wheat was permitted, but not wheat from a particular field. See id. Other rules also existed, requiring precise specifications on weight and type, for example. See SanHuri, supra note 120, at 34.

155. See Vogel \& HAYES, supra note 6 , at 89.

156. See SANHURI, supra note 120 , at 38 . This existed in the classical era as well. See Abu BaKr ibN Mas'ud Kasani, 7 Bada'l Al-SANA'I fi TARTIB Al-Shara'i 2167-69 (Zakariya 'Ali Yusif ed., 1968)

157. See SANHURI, supra note 120 , at 38-39. The majority of classical Hanafi jurists held istisna contracts to be non-binding in their entirety until the goods had been manufactured and the buyer had the opportunity to inspect them. See KaSANi, supra note 156, at 3168-69 (indicating that the non-binding nature of istisna derives directly from the fact that it is a product of judicial preference and departs from the rule of qiyas). However, there was a minority opinion from the early Hanafi jurist, Abu Yusuf, holding that 


\section{The Failures of Islamic Commercial Jurisprudence-The Consequences of Langdellianism}

\section{A. Original Conceptions}

The foundational element of the alternative fairness-based architecture, which the proponents of Islamic finance first envisaged as complying with the rules of gharar and riba under their modalities, was the mudharaba, an Islamic form of passive partnership. ${ }^{158}$ In a mudharaba, passive investors place their capital in a venture, other participants contribute only their labor, profits are distributed first to the investors until their investment is recouped, and the remaining profits are then distributed based on an agreed upon percentage. ${ }^{159}$ Those contributing their labor would bear no capital risk. ${ }^{160}$

As originally envisaged, Muslims would passively "invest" in the Islamic "banks" through deposits, and the banks would then invest as passive partners in various ventures. ${ }^{161}$ Profits from the ventures would be distributed to the partners of the Islamic bank and the managers of the ventures based on an agreed upon percentage. ${ }^{162}$ Thus, this model would avoid debt and derive all profits derived from genuine gain. Passive partners would exclusively bear all losses. ${ }^{163}$

Unfortunately, as might be expected of a legal system developed with scant concern for discretionary preference or practical reality, this model is commercially unworkable as an alternative to the conventional bank system because it offers neither the liquidity nor the minimal risk of loss that would be expected of a bank. ${ }^{164}$ For example, private equity funds currently operate on principles of limited partnership very similar to those envisaged by the early Islamic financiers. ${ }^{165}$ However, because of the con-

istisna contracts were binding at the time of the offer, not acceptance, considering the hardship that would exist if either party refused to enter into the contract after the goods had been manufactured. See id. at 3169 .

158. See Vogel \& HAYES, supra note 6, at 130-31; see also SIDDIQI, supra note 26 , at 86 ; see also Usmani, supra note 24 , at 10 . Sadr seems to have adopted this principle as well. See Al-Bank, supra note 17, at 154 (indicating that the first principle of lending policy should be the transformation of loans into partnership transactions where possible).

159. See VOGEL \& HAYES, supra note 6, at 109-10.

160. See id.

161. See id. at 131; see also WARDE, supra note 9, at 135-36; see also AL-BANK, supra note 17 , at 154 .

162. See Vogel \& HAYES, supra note 6, at 131; see also WARDE, supra note 9, at 135-36; see also AL-BANK, supra note 17, at 154.

163. See VOGEL \& HAYES, supra note 6, at 109-10.

164. As to whether or not such a system, even if it were somehow workable, is necessarily fairer than interest-based banking, there can be considerable doubt. The financial institution would only be entitled to share in gains in the venture, but given that there are few limitations on the percentage of profits that an investor may earn in a venture, the transaction could be considerably less equitable than debt. See Vogel \& Hayes, supra note 6 , at 81 ; see also Kuran, supra note 28 , at 178 . For example, an entrepreneur may well regard a $6 \%$ guaranteed return to a bank as considerably fairer than a $90: 10$ division of profit in favor of an investor.

165. For more detailed information on the structure of private equity funds, see JAMES M. Schell, Private Equity Funds: Business Structure and Operations $\$ 301$ (2000). In 
siderable risk of loss, annualized internal rates of return to the passive limited partners are expected to net significantly higher gains than investment in a bank. ${ }^{166}$ Moreover, Islamic banks would have less liquidity than conventional banks if they relied solely on mudharaba. For example, if depositors at an Islamic bank react to unexpected losses by rushing to withdraw their funds, then an Islamic bank would have no recourse to quick liquidity through discounting current debt obligations or borrowing from a central bank with interest. ${ }^{167}$

Another difficulty in using the mudharaba paradigm is that banks do not generally have the capacity to monitor their many investments in ventures. ${ }^{168}$ Again, juxtaposing the paradigm of the private equity fund, funds generally deeply involve themselves in the management of the few underlying ventures in which they invest, and the funds also demand significant shareholder rights, such as a director's seat, veto over significant changes to the business, rights to review financial records, and rights to purchase the interest of any other investor seeking to dispose of his investment. ${ }^{169}$ Commercial banks generally do not engage in this type of costly exercise because they are guaranteed a fixed return on their investment in the form of an interest payment. ${ }^{170}$ If an Islamic bank were to engage in the same extensive and costly practices as an equity fund with respect to every investment made, it would raise its costs substantially, severely compromising its ability to compete with commercial banks. ${ }^{171}$ However, if it chose to forego this, the bank would expose itself to the possibility that financial records were being falsified, or at least accounting standards interpreted in a way that minimized distributed profits. ${ }^{172}$ There is some evidence that this is precisely what happened to early Islamic banks that attempted to apply the mudharaba model. ${ }^{173}$

It is possible that the financial institution could avoid these problems simply by investing in highly liquid, low risk, and low return equities, much as a "money market" fund tends to do, but then it would not serve

addition, the author has had extensive experience in the structuring and deployment of private equity funds.

166. See id. $\S \S 2.02-2.04$. Most private equity funds require that revenue first be distributed exclusively to the limited partner investors, not only to the extent of their investment, but also to a preferred return level of approximately 6 to $7 \%$. See id. $\S 2.03$. Fund managers are entitled only to profits, ironically and misleadingly termed "carried interest," above this level at a specified percentage, usually $20 \%$. See id. $\$ 2.02$.

167. See Vogel \& Hayes, supra note 6 , at 134 .

168. See Vogel \& HAYES, supra note 6, at 135; see also Timur Kuran, The Economic System in Contemporary Islamic Thought, 18 lNT'L J. Middle E. STud. 135, 153 (1986).

169. See generally Schell, supra note 165, $\$ \$ 1.01-1.07$. Admittedly, private equity funds at times insist on some of these provisions, and, in particular, seats on the board of directors for regulatory reasons unrelated to monitoring. See id. § 8.06(4).

170. See id. Commercial banks may seek some control over key decision-making with respect to parts of a venture, such as a sale of the business, particularly for larger loans. However, the level of control is generally much smaller than it would be for a private equity fund.

171. See id.

172. See Vogel \& HAYES, supra note 6, at 135.

173. See id. 
the market role that a bank would. A bank as a financial intermediary is supposed to overcome particular market failures concerning economies of scale, information asymmetry, and liquidity mismatches that would otherwise develop. It collects the funds of many unsophisticated depositors who need quick access to their funds and uses expertise and specialized skills to identify and monitor to some extent its portfolio, earning interest from the portfolio and having sufficient ready liquid cash on hand to satisfy the requirements of its depositors. ${ }^{174}$ If it were to forgo these opportunities and merely act as a money market fund, it would never be a substitute for a conventional bank, and conventional banks would continue to be necessary.

\section{B. Alternative Approaches Within the Langdellian Modalities}

Given the foregoing, Islamic financial institutions have found themselves in an existential crisis that has lasted to this day. The entire foundation upon which the institutions had expected to rest, the mudharaba, had proved incapable of sustaining them, and no ready alternative methodology was apparent.

Moreover, given the Langdellian modalities within which contemporary Islamic jurisprudence willfully imprisoned itself, the flexibility necessary to develop an alternative legal architecture responsive to the commercial demands of the modern era was severely limited. The doctrines of riba and gharar had been developed through strict application of these modalities. Little could be changed by an application of the same reductive methodology, and, in any event, many of the rules had been confirmed by ijma with only a few exceptions, most of them casuistic. ${ }^{175}$ The fundamental principles had been laid, and they could not sustain a sensible commercial jurisprudence. The doctrines and the modalities that gave rise to them needed to be abandoned, or at least fundamentally reconsidered.

Islamic commercial jurisprudence has not risen to this challenge. Rather than address the problem directly by seeking an alternative system that is cognizant of commercial reality and sensitive to populist demands for social justice, Islamic financial institutions have largely fallen back on obfuscation, complication, and implicit deception. Islamic financial institutions rely primarily on three basic commercial structures, ${ }^{176}$ and each is an artifice. In addition, discussed below is the problem of insurance, a vitally important commercial arrangement that clearly falls within the prohibitions of gharar and riba according to Islamic finance practitioners. .

174. See Mahmoud El-Gamal, Islamic Bank Corporate Governance and Regulation: A Call for Mutualization, at 7, available at http://www.ruf.rice.edu/-elgamal/files/ IBCGR.pdf.

175. See El-Gamal, supra note 15.

176. See generally Vogel \& HAYES, supra note 6, at 138-49. 


\section{Murabaha}

Murabaha is the principal tool of the Islamic financial institution. By one estimate, approximately $80-95 \%$ of the funds of Islamic financial institutions are employed in murabaha transactions. ${ }^{177}$ A murabaha is basically the sale of an item with a fully disclosed markup. ${ }^{178}$ As used by financial institutions, however, the murabaha is effectively an artifice through which interest may be charged without falling afoul of the prohibition of riba. A financial institution purchases some asset and simultaneously sells it to the effective borrower at a higher price. ${ }^{179}$ The borrower's payment is delayed for the desired term, with the price to the ultimate purchaser reflecting the prevailing market interest rate. ${ }^{180}$ The final step of the transaction in some cases is that the borrower sells the asset to recover what is effectively the loan principal.

The sole legal difference between this resale of an asset and an interest-based transaction relates to ownership of and liability for the asset during the time of transfer. However, these differences are obliterated by provisions in murabaha transactions that declare the sale to the effective borrower as occurring simultaneously with the first purchase by the Islamic financial institution. ${ }^{181}$ The bor rower also waives all claims against the financial institution for breach of warranty, and the financial institution assigns all of its similar rights as the original purchaser to the borrower. ${ }^{182}$ As might be expected, the murabaha usually involves the purchase and sale of a readily resalable commodity, so that all connection to the asset purchased is illusory. ${ }^{183}$

To expound on an example set forth by Vogel and Hayes, if a borrower sought credit from a conventional bank in the amount of $\$ 50,000$ at an interest rate of $8.5 \%$, with repayment to be made in nine equal monthly installments, she would be required to pay $\$ 5,754.17$ per month. ${ }^{184}$ Alternatively, she could go to an Islamic financial institution and purchase stock in IBM currently valued at $\$ 50,000$ while agreeing to pay for them in nine monthly installments of $\$ 5,754.17$. The bank's purchase of the stock from the market would be simultaneous with her purchase of the stock. She could then have a broker (perhaps employed at the same financial institution) sell the stock immediately thereafter and deposit the $\$ 50,000$ into her account. In an increasingly popular variant of the murabaha, known as tawarruq, the borrower would sell the purchased asset back to

177. See W ARDE, supra note 9 , at 133 ; see also Vogel \& HAYES, supra note 6 , at 198 .

178. See WARDE, supra note 9 , at 140.

179. See id. at 140-41.

180. See id. at 139. Banks are often eager to appear not to be engaged in such obvious artifice and seek to disguise their murabaha transactions in a slightly less vulgar manner. Id. (indicating the reluctance of Islamic financial institutions to make explicit references to prevailing interest rates despite their reliance on them).

181. See id. at 141 .

182. See id.

183. See id at 143 .

184. See id. at 177. 
the original seller from whom the bank purchased it. ${ }^{185}$

Given the obvious transparency of most murabaha transactions, they have proven somewhat controversial. Many jurists have denounced them, at least in their current form, and the Fiqh Academy of the Organization of Islamic Conference, probably the dominant Islamic jurisprudential authority with respect to matters of finance, has shown some discomfort with the approach even as it has sanctioned it. ${ }^{186}$ The Gulf Cooperation Council has been considerably more flexible, sanctioning both the murabaha and its tawarruq manifestations. ${ }^{187}$ Few within the Islamic finance community would describe the murabaha as entirely violative of Islamic law; Islamic financial institutions could not at this point survive without it.

\section{2. ljara}

Ijara, or lease, transactions represent a rapidly growing segment of the Islamic finance sector. ${ }^{188}$ Ijara is barely less transparent than the murabaha, and conceptually similar to a conventional lease in that it permits a bank to purchase an item and lease it to a third party at whatever price the lessor and the lessee deem fit. ${ }^{189}$ Three theoretical differences arise between ijara and conventional interest-based financing, but all three are ignored in Islamic commercial arrangements, often in clear contravention of the shari'a.

First, a floating interest loan would be impossible, as uncertainties in price at the time of contracting would violate the gharar prohibition. To avoid this, banks routinely offer renewable leases with the lease value shifting to conform to the prevailing interest rate at each renewal. ${ }^{190}$ Though either party can in theory cancel the renewable lease, in practice, this is never the case and commercial actors rely on business reputation, internal understandings and non-binding good faith agreements indicating that the lease will be periodically renewed. ${ }^{191}$ When these informal understandings are not enough, Islamic commercial actors simply draft the provisions they prefer, in this case compulsory renewals of the lease, and select a law to govern the arrangement that is not the shari'a. ${ }^{192}$ This is exceedingly common, ${ }^{193}$ even if a highly disingenuous, hypocritical, and obfuscatory measure given the professed desire to practice a specifically Islamic form of commerce.

185. See supra note 5 .

186. See Vogel \& Hayes, supra note 6 , at 143; see also Muhammad Nejatullah Siddigi, IsSUES IN ISLAMIC BANKING 49 (1983); SAleH, supra note 130, at 118-19.

187. El-Gamal, supra note 5, at 9.

188. See VOGEL \& HAYES, supra note 6, at 144.

189. See id.

190. See id.

191. See id.

192. See id. at 263; see also Moghul \& Ahmed, supra note 2, at 189-90 ("IP]arties to Islamic finance transactions often assert English or New York law as the governing law on the probability that the contracts are more likely to be enforced as written.").

193. See Vogel. \& HAYES, supra note 6, at 263; see also Moghul \& Ahmed, supra note 2 , at $1.89-90$. 
Second, gharar also requires ijara arrangements to be cancellable at will because of the uncertainty in the future value of the leased property. ${ }^{194}$ This problem is addressed the same way as a renewable lease-by contracting in violation of the shari'a or by relying on business reputation and an informal understanding. ${ }^{195}$

A third and final difference is that the lessor, as the owner of the property, must be responsible for all expenses related to its upkeep, on the theory that gharar prohibits placing an uncertain obligation of this sort on the lessee. ${ }^{196}$ Again, commercial actors routinely ignore this rule and either require the lessee to pay for the upkeep or purchase casualty insurance. ${ }^{197}$ Neither of these options complies with the rules established by the Langdellian modalities. ${ }^{198}$

\section{Istisna'/Salam}

Istisna' is a limited exception developed through istihsan to the prohibitions on the sale of nonexistent objects as derived by qiyas and ijma'. ${ }^{199}$ The broader type of advance purchase permitted by a specific hadith was salam, or full advance payment for a generic product to be delivered at a later time. Thus, istisna', with its more flexible payment terms, did not cover the more general products that were permitted under the doctrine of salam, as it dealt exclusively with manufacture. ${ }^{200}$ Moreover, because it is based on the discretionary istihsan, it is supposed to be used very sparingly. ${ }^{201}$ However, Islamic financiers have reversed the presumption, and activities permitted under istisna' are now the rule rather than the exception. ${ }^{202}$ As a result, they now use the terms salam and istisna' nearly interchangeably, applying the rules of istisna' to both. ${ }^{203}$ This approach is particularly ironic given the apparent reluctance of Islamic financiers generally to overhaul the underlying Langdellian bases that have relegated istihsan to such a minor role in the development of Islamic jurisprudence. If the anti-formalist tool of istihsan is permitted to do such considerable violence to the fundamental Langdellian principle derived from the Prophetic hadith that the sale of nonexistent objects is prohibited, then one wonders why it could not also be used, for example, to do equal or lesser violence to the prohibitions against interest.

In any event, istisna' permits a financial institution to request the construction of a particular item, such as a house, and to pay for it in, for

194. See Vogel \& HaYes, supra note 6 , at 144 .

195. See id. at 145 .

196. See id. at 144 .

197. See id. at 145 .

198. See id. at 150 .

199. See RAYNER, supra note 134 , at $27,137-38$.

200. This is obvious from the definition of the term istisna, which means, "to have someone make something." WEHR, supra note 93, at 615 .

201. See SANHURI, supra note 120 , at 38 .

202. See Vogel \& HAYEs, supra note 6 , at $146-47$.

203. See id. at $146-49$. 
example, three annual installments. ${ }^{204}$ A second istisna' could then be concluded selling that same house to a prospective homeowner through a longer series of monthly installments extending, for example, over 25 years. ${ }^{205}$ This arrangement renders any profit or risk sharing on the part of the financial institution entirely illusory, as it is in all material respects a fixed interest mortgage. ${ }^{206}$

\section{A Problem of Insurance}

As derived under the Langdellian modalities, the prohibition against insurance is firm and absolute, according to practitioners of Islamic finance. Commercial insurance both involves indirect investment in riba, as most insurance companies place a large amount of their funds in interest bearing accounts, and, more importantly, it involves payment of premiums in exchange for a sum that may or may not ever be received based on an entirely unpredictable future contingent event. ${ }^{207}$

Islamic finance has developed an artifice known as a takaful, or solidarity, contract to circumvent the prohibition. ${ }^{208}$ Takaful derives from the determination by some scholars that gratuitous contracts are exempt from the rules of gharar. 209 Pursuant to takaful, a group of Muslims agrees to protect its members in the case of casualty or loss by pooling their resources through making regular payments, in the form of premiums, to be invested in Islamically acceptable commercial products. ${ }^{210}$ The scheme then functions in theory as an Islamic financial institution would, with "profits" shared amongst the beneficiaries and the providers. ${ }^{211}$ When a casualty or loss occurs, the participants each "gift" a portion of the asset pool to the bearer of the loss. 212

204. See id. at $146-47$.

205. See id.

206. See id.

207. See id. at 150. The gharar violation is more fundamental, as insurance companies presumably could avoid the receipt of riba more readily than they could the uncertainty that constitutes their reason for existence. It should be noted, however, that some have argued that even under current concepts of gharar, insurance is permissible because it is not the payment of premiums in the hope of receiving a payoff in the future, but rather payment for a particular, certain service that is easily valued, avoidance of risk. This is akin, under such a formulation, to paying a guard to protect one's goods. It suffices to say for purposes of this Article, however, that this position has not gathered very much support at all within the Islamic finance community. See Vogel and Haes, supra note 6, at 150 (referencing work of Mustafa Zarqa).

208. See id. at 151.

209. See id. at 151. For a classical reference, see IBN RuSHD, supra note 147, at 399 ("[A]ll which cannot be sold legitimately from the standpoint of gharar [may be gifted].").

210. See Vogel \& Hayes, supra note 6 , at 151-52.

211. See Mohd. Ma'sum Billah, Principles \& Practices of Takaful and Insurance COMPAREd 25 (2001).

212. See id. Many seemingly respected advocates of Islamic finance strive mightily to find alternative grounds upon which the doctrine of takaful might be grounded. See generally Mohd. Ma'sum Billah, Sources of Law Affecting 'Takaful', 2 INT'L J. IsLAMIC Fin. SERVICES 4, available at http://islamic-finance.net/journals/journal8/mmbillahvol2no4. pdf. These grounds vary from a Prophetic recommendation that one take precautionary 
This approach is problematic for several reasons. First, the gift seems to require that an offeror be bound before the identity of the receiver of the gift or the value of the gift is even known, a difficult proposition to sustain as a general matter. ${ }^{213}$ Second, the notion of a group of friendly and brotherly Muslims agreeing to support each other in times of need becomes especially difficult to sustain as economies of scale increase in size, and the number of participants grows so that they no longer have any personal or commercial relationship with each other. However, most importantly, institutions offering takaful products are not acting gratuitously. ${ }^{214}$ The donations made by the participants in the scheme function in all respects like Islamic banking accounts. This disingenuous reference to charitable activity is inherently deceptive to prospective purchasers of the product and potentially damaging to regulatory frameworks in the operable jurisdictions. This is a for profit contract, and a straightforward application of the rules of gharar must invalidate it if the modalities are taken seriously.

In some cases, this descent into jurisprudential delusion is taken a step further. Islamic financial institutions often purchase general commercial insurance on the grounds that takaful insurance is not available to the extent that the bank needs it, and commercial necessity demands that some form of insurance be available. ${ }^{215}$ Otherwise, the bank justifies the purchase on the grounds that commercial insurance itself can be considered a form of takaful. ${ }^{216}$ The former approach is essentially an admission that the Langdellian modalities have failed to address commercial realities despite their willingness to employ the most transparent of techniques to achieve standard financial objectives. The latter approach is even less grounded in commercial realities, as a legal doctrine that relies on the clas-

measures to ensure that a camel does not flee to Prophetic blessings upon those who remove hardships from Muslim brothers. See id. By and large, none of them is sensible enough to rebut, other than to indicate that they deal with recommended measures that have absolutely nothing to do with gharar. One of the most popular alternative grounds appears to be based upon the Muslim penal doctrine known as aqilah, pursuant to which particular members of a tribe are jointly responsible for the payment of blood money to the family of a victim killed by the tribe. See id.; see also BILLAH, supra note 211, at 3-6; Yon Bahiah Wan Aris, Takaful-An Option to Conventional Insurance: A Malaysian Model (2004), available at http://www.icmif.org/2k4takaful/site/documents/ an\%20option $\% 20$ to $\% 20$ conventional\%20insurance.pdf; Muhammad Ayub, Takaful-An Alternative to Insurance, available at http://www.sbp.org.pk/departments/ibd/Takaful. pdf. Precisely what such an obligation in the penal law has to do with contractual rules concerning gharar mystifies the author, and the fact that respected Islamic professors and directors of banking operations make such logically fatuous claims demonstrates the Islamic banking community's discomfort with the bases upon which the practice of takaful rests.

213. This approach certainly would violate the classical rules concerning gifts, which require at least an offer and acceptance by a known individual of a known object. See IBN Rushd, supra note 147 , at 361 .

214. Takaful contracts are generally offered by large financial institutions in the Islamic world. See, e.g., International Cooperative and Mutual Insurance Federation, Takaful Directory, http://www.icmif.org/2k4takaful/site/directory.asp.

215. See VOGEl \& HAYEs, supra note 6, at 152. The Islamic Development Bank, perhaps the world's largest Islamic bank, adopts this approach. See id.

216. See id. 
sification of standard commercial insurance providers as charitable institutions is patently absurd.

\section{Langdellianism and Islamic Finance}

In their consequential failures, Langdellianism and Islamic jurisprudential theory mirror each other almost entirely. Part I of this Article mentioned four primary causes for the fall of Langdellianism: (1) failure to articulate its own ontological constituent units; (2) inability to admit the possibility of inconsistent rules within the modality which necessarily resulted in judicial discretion; (3) separation from the experiential realities in which the law operates, leading to willful abandonment of its principles by judges and juries alike; and (4) imperviousness to change in a rapidly changing social and economic environment. All of these, save the first, are equally applicable in the Islamic context.

Proponents of the modalities will often apply doctrines in wildly inconsistent manners. For example, they will decry as defeatist or apologetic any suggestion that istihsan, or any other doctrine, should be used to exempt money loans from a hadith that deals fundamentally with trades of items, such as precious metals and foodstuffs, which are not the contemporary basis of currency. Yet proponents permit the practice of istisna, all but obliterating the former fundamental principle that sales of nonexistent objects are forbidden, which is a far greater use of istihsan. ${ }^{217}$ The quasiscientific approach appears not to provide the level of certainty intended.

When this implicit discretion is insufficient to achieve a desired result, even proponents of the modalities will ignore the methodological principles to which they claim obedience. This departure from legal requirements might be achieved directly, by requiring a lessee to pay for upkeep of property he leases notwithstanding the Islamic prohibition, or indirectly, by creating such nonsensical concepts as charitable insurance. In either event, as with Langdell in the American context, the modalities are often unworkable and consequently unheeded despite claims of adherence to them.

Finally, the Islamic Langdellian modalities are impervious to the types of changes required to develop a sensible commercial jurisprudence. The rules of riba and gharar are now ironclad through reductive understandings of ijma and cannot be altered without abandoning the modality. As a

217. These stark inconsistencies often arise from the fact that the modern proponents of Islamic finance tend to presume all classical jurists have applied the Langdellian modalities faithfully, and, in a process known as takhayyur, pick and choose among disparate classical rules, like spare parts at a junkyard, selecting that which seems more convenient and in keeping with commercial reality. See An-Na'im, supra note 124, at 45 (describing takhayyur). For example, as the classical Hanafi jurist, Kasani, provides for the practice of istisna in his writings, proponents of Islamic finance accept and substantially expand the practice. See KASANI, supra note 156; see also Muhammad Al-Bashir Muhammad Al-Amine, Istisna' and its Application in Islamic Banking, 16 ARAB L.Q. 22 (2001). Compare supra note 128 (discussing a late classical rule with no basis for support in the Langdellian modalities that is nonetheless relied upon by proponents of Islamic finans:). 
result, jurists continue to struggle with concepts as basic as insurance and interest on debt, developing extensive artifices to address them while the modern commercial world races ahead with financial and commercial innovations far more complex. The author does not doubt that further artifice and fiction may develop to deal with commercial innovation. However, it will become less and less clear what the benefits of Langdellian jurisprudential theory precisely are, while the increasing transaction costs caused by the unnecessary complexity will surely come under hightened scrutiny. Those who looked to Islamic finance to create a more just and equitable system will no doubt begin to look elsewhere, as the shari'a developed under the Langdellian hermeneutic is not meeting the needs of Muslims.

\section{Alternative Approaches}

The task remains to determine whether the shari'a can play a salutary role in the commercial lives of the Muslim body politic, and, if so, exactly what type of jurisprudential approach should replace the Langdellian modality that currently dominates. 218

Continuing the comparison to American intellectual and academic tradition further than this Article has so far could invite something akin to the more extreme forms of American Legal Realism in the Islamic juristic tradition. Such an approach would consider doctrine entirely irrelevant to rulemaking, rendering questions as to whether a particular transaction were riba or bai an exercise in "transcendental nonsense."219 Jurisprudence of this sort would pay heed solely to policy-based notions of fairness and social justice, social, political and commercial reality, and whatever other factors, including personal biases and prejudices, might matter to the decision-maker. This would not be likely to succeed in the Islamic world. ${ }^{220}$ Muslims, as a general matter, probably would not ignore all of traditional Islamic doctrine in fashioning a code of conduct. Most Muslims would probably regard an approach that advocated a complete departure from the Qur'an and the hadith as entirely illegitimate from an Islamic perspective, regardless whether it reflected notions of fairness and social justice. ${ }^{221}$

218. Realistically, modern commercially successful nations will not reformulate their entire banking structures on Islamic principles at any point in the near future, regardless of how those principles are defined. However, as is currently the case in Malaysia, nations could very well tolerate, and even encourage, a separate Islamic financial system operating alongside the conventional one. See WARDE, supra note 9, at 123 . The current section therefore contemplates the possibility of such a parallel approach.

219. Felix S. Cohen, Transcendental Nonsense and the Functional Approach, 35 Colum. L. Rev. 809, 820 (1935).

220. Cf. Jackson, supra note 38 (developing an approach drawn largely from Roberto Unger and Stanley Fish).

221. Of course, this approach would be somewhat marginal within the judiciary in the American context as well, because total disregard for the orthodox bases on which judges render decisions, such as sound interpretation of constitutional text, is hardly characteristic of the manner in which most opinions are written. Professor Fletcher properly points out that American legal culture tends to view the Constitution as similar to a religious text in many ways, such as its reluctance to seek amendments, its refusal to delete amended text even when the text is offensive to modern sensibilities, and its his- 
In light of this, it is important to establish principles for alternative approaches towards Islamic finance that would ensure both credibility and achievement of ontological objectives. ${ }^{222}$ These would lay the groundwork for, but would not establish in exact detail, alternative methodologies. Four basic principles are apparent, and each is discussed in turn.

\section{A. Qur'anic Maxims}

The methodology necessary to reformulate Islamic finance could and should claim strict adherence to the Qur'an's text. Given the lack of definition afforded to riba, the Qur'an's passages present no obstacle to a sensible jurisprudence that harmonizes commercial reality with some modicum of social justice. In fact, the prohibition of riba can contribute to the creation of a social justice framework. Other verses that permit commerce, urge believers to honor their contracts, and forbid games of chance seem equally salutary standing on their own, posing no impediment to the creation of a sound modern economy. ${ }^{223}$

toric internal battles between literalists and those who seek to follow the spirit rather than the letter of the text. See George P. Fletcher, Three Nearly Sacred Books in Western Law, 54 ARK. L. REv. 1, 3-8 (2001).

222. The approach herein is primarily jurisprudential, advocating alternative means of developing legal doctrine to serve functional ends. The author would be remiss for this Article not to mention parallel efforts by the economist Professor El-Gamal to develop economic proposals to conform to what El-Gamal describes as the "spirit" of the riba and gharar prohibitions. El-Gamal, supra note 174, at 12-15. Professor El-Gamal argues that a solution for Islamic banks and insurance companies would be to adopt the mutual form, where the depositors are themselves the shareholders to the extent of their deposits. Id. at 15. The managers of mutual institutions avoid excessive and potentially exploitative risk-taking in commercial transactions because they face no need to raise stock prices. Id. While there is much to be said in favor of El-Gamal's ideas, gaps in his ideas exist from his understandable decision not to confront legal doctrine, as this Article seeks to do. Specifically, it is difficult to see absent a functional jurisprudence how El-Gamal's vague notions of "spirit" could be realized in practice. The dominant formalists would insist that their practice is no less Islamic given its compliance with shari'a and, absent jurisprudential reformulations, little could be said in response to such a claim.

223. This is emphatically not the case with respect to other legal realms where some of the Qur'an's passages do create substantial problems. These include the plainly gender discriminatory verses on inheritance, see QUR'AN 4:1 1; the sanctioning of polygamy, see QUR'AN 4:3; spousal abuse in certain circumstances, see QUR'AN 4:34; severe corporal punishment for consensual sexual activity, see QUR'AN 24:2; and the suggestion of some verses, contradicted by others, to kill unbelievers wherever they might be found, see QUR'AN 9:5. But see QUR'AN 16:126 (urging tolerance even of unbelievers who commit some sort of transgression). Reform-minded methodologies have been advanced to address these issues. See, e.g., An-Na'im, supra note 64, at 52-60 (discussing the approach of a prominent Sudanese jurist calling for abrogation of the problematic verses on the grounds that earlier contradictory verses speak to the fundamental dignity of all persons and were meant to be universal, while the problematic passages related to rules delivered to a specific society at a specific time); Bernard K. Freamon, Slavery, Freedom, and the Doctrine of Consensus in Islamic Jurisprudence, 11 Harv. Hum. RTs. J. 1, 56-64 (1998) (arguing persuasively for a liberalized version of ijma to take precedence over Qur'anic verses that presuppose the existence of slavery). Nevertheless, despite these attempts, to the extent that Qur'anic maxims are not followed in Islamic nations, it is not because of a comprehensive reexamination of the verses, but rather their replacement with secular codes. See Weiss, supra note 35 , at 188 . This has led An-Na'im to advocate 


\section{B. The Roles of Hadith, Istihsan, and Istislah: An Examination of Sanhuri and Sadr}

While significant portions of the hadith may be apocryphal, they are generally deemed to be the utterances of the Apostle of God and, therefore, constitute a significant part of any Islamic jurisprudence. Moreover, as much of the ritual aspects of Islamic practice are bound to the hadith, any attempt to divorce Islam from the hadith would so unmoor the traditional bases of Islamic thought that the religion would be scarcely recognizable to its adherents. ${ }^{224}$

However, unlike the Qur'an, absolute compliance to the terms of the hadith and, more importantly, their reductionist expansion through qiyas is not possible if a sensible alternative modality is to be constructed. If hadith prohibiting the sale of the fish in the sea and the trade of precious metals with unilateral excess in value are not only followed but interpreted and expanded through the doctrine of qiyas in the manner of modern Islamic finance, then the same, or similar, problems as exist now will inevitably reemerge. The hadith must be taken seriously as constituent elements of Islamic doctrine, and qiyas need not be abandoned in its entirety, but the roles of istislah and istihsan in applying the hadith itself must be substantially increased. ${ }^{225}$ This has considerably more purchase among the Mus-

an alternative Islamic solution that might be termed secular, in which the shari'a is not the positive law of the State. Abdullahi An-Naim, Shari'a and Positive Legislation: Is an Islamic State Possible or Viable?, in 5 Yearbook of ISLAmic and Middle EASTERn Law 3031 (Eugene Cotran and Chibli Mallat eds., 1999). An-Na'im points out that the development of the shari'a, with its divergent opinions among jurists in the classical era, clashes conceptually with the manner in which positive legislation is enacted by a state. The political organs of a state, including its legislature, cannot really be expected to select among the various conflicting juristic rules constituting the shari' $a$ and deem whatever politically expedient solution emerged to be the Divine Command of God. See id. at 3236. An-Na'im's work is bold and noteworthy, though orthogonal to the purposes of this Article. Even if one were to assume a total separation of positive legislation from the shari'a, an alternative Islamic financial system functioning alongside that of the State, as is the case in Malaysia currently, could still play a salutary role in Islamic societies and ideas on alternative modalities would still prove useful in the context of Islamic finance.

224. See, e.g., RisalA, supra note 70, 9T 535-37, 613-18 (pointing out correctly that the hadith often provides context to Islamic ritualistic practice).

225. It should also be noted that an increasingly visible role for istislah and istihsan is not an idea that has been invented by this author. For example, Professor John Esposito has spoken favorably about both istihsan and istislah. See John L. Esposito, Perspectives on Islamic Law Reform, 13 N.Y.U. J. INT'L L. \& POL. 217, 241-42 (1980); see also ANNA'IM, supra note 64 , at 51 (referring to a fourteenth century jurist with similar ideas). Moreover, much of this notion of reformulating the competing roles of qiyas, istihsan and istislah is often subsumed under the rubric of a call for ijtihad, or independent juristic reasoning. See, e.g., Esposito, supra note 225, at 241-42; MALLAT, supra note 17, at $124-26$ (describing Sadr's theory in terms that sound remarkably like a form of istislah). This call arises from the fact that Muslim legend holds that at some point at the end of the 12 th century jurists agreed by ijma that there was no purpose to further development of modalities and rules, and supposedly "closed the doors" of ijtihad. Coulson, supra note 65, at 81, 202; contra Wael B. Hallaq, Was the Gate of ljtihad Closed?, 16 INT'l J. Middle E. STud. 3, 4 (1984) (suggesting that the fabled "closing of the doors" never in fact happened). Rather than reason independently, later jurists were expected to follow faithfully the theories of their predecessors through a process known as taqlid. See Origins, supra note 69 , at 121-23 (describing the distinction between 
lim body politic than any suggestion that the Qur'an's verses be reevaluated, and seminal jurists and legal scholars, such as Sanhuri and Sadr, have taken ginger steps in this direction.

\section{Sanhuri's Definitional Approach}

Sanhuri has an alternative interpretation of the historic prohibition of riba that is built upon both the sanctity of the Qur'an and substantial respect for the hadith. ${ }^{226}$ For ease of reference, and because of its emphasis on determining what the hadith are precisely supposed to mean in light of Qur'anic verse, the author calls this approach the "definitional" approach or theory.

Sanhuri argues that the language of the Prophetic hadith on riba aljahiliyya, along with a reading of the Qur'anic verses on the subject, suggests that the central Qur'anic prohibition concerned only the form of riba, where a debtor was told on the due date of his loan that he either needed to make payment in full or the amount due would increase. ${ }^{227}$ While Sanhuri does not disregard the prohibitions in the hadith on delayed or unequal exchanges that lead to the interest prohibition, he does suggest that they are prohibitions of means (tahreem wasa'il), and that their purpose is to prevent commercial actors from circumventing the central Qur'anic prohibition (tahreem maqasid) of riba al-jahiliyya. ${ }^{228}$ Therefore, Sanhuri reasons, as the prohibitions on trade are of means, they may be set aside in cases of need (haja), unlike the central intended prohibition, which may never be set aside. ${ }^{229}$ Sanhuri indicates that need is a preponderance of the public interest (al maslaha al rajiha), which in the modern era clearly points to permitting debt. ${ }^{230}$ Therefore, the only riba prohibition would be on agreements to increase the value of a loan in exchange for an extension.

The argument turns the Langdellian modalities on their head. Rather than search the hadith for the fundamental principles, Sanhuri looks first to the Qur'an, then defines on the basis of the Qur'an and the hadith exactly what policy the Qur'anic provision is meant to further and subsequently reduces the Prophetic hadith not centered on the Qur'anic prohibition to some sort of subsidiary repealable status, implicitly to be evaluated

ijtihad and taqlid). The prominent jurist Muhammad Abdu in the early part of the twentieth century called for the doors of ijtihad to be reopened, and this has become a battle cry of sorts for reform of every conceivable variety. See, e.g., Coulson, supra note 65, at 201-02; Irshad Manji, The Trouble with Islam: a Muslim's Call for Reform of Her FAITH 158-86 (2003) (using the term ijtihad to propose broad changes to the substance of shari'a, including abrogation of Qur'anic verses). While the term ijtihad hardly has any definable methodology attached to it, in the modern era, proponents of ijtihad, such as Sadr and $\mathrm{Abdu}$, generally seek an expansive use of reason to develop creative Islamic solutions to the problems of modern society while still remaining essentially faithful to the Qur'an and hadith. See MALLAT, supra note 17 , at 124 . This effectively is a reorganization of the relative priorities of istislah, istihsan, and qiyas.

226. See SANHURI, supra note 120.

227. See id. at 241-42.

228. See id. at 242.

229. See id. at 242-43.

230. See id. at 243. 
on the basis of istislah or istihsan. ${ }^{231}$ Sanhuri's definitional solution is not entirely satisfactory, as it seems to prevent or complicate debt restructuring, which is a non-exploitative practice, and does nothing to reformulate riba in a manner that accords with contemporary notions of social justice. However, it lays the groundwork for a possible approach that shows promise.

Though Sanhuri does not apply his definitional theory to gharar, it could apply equally well. The Qur'anic prohibition clearly refers to games of chance and divination, as opposed to commercial activity, and this, therefore, is the intended prohibition. ${ }^{232}$ Prohibitions against particular commercial uncertainties, such as the sale of a pregnant camel, are effectively prohibitions of means to prevent parties from being able to circumvent the intended prohibition through artifice. ${ }^{233}$ Therefore, the hadith may be set aside given the need for commercial transactions involving uncertainty. This would limit gharar so that it did not impose any substantial constraints on commercial practices, but would not allow gharar to serve any social justice function either.

\section{Sadr's Contextual Approach}

The Iraqi Shi'i jurist, Muhammad Baqir al-Sadr, is one of the founders of Islamic economics, a staunch opponent of interest, and a highly respected jurist, primarily among Shi'is. Sadr suggested a flexible approach to hadith different from Sanhuri's. ${ }^{234}$ Sadr's Islamist credentials are beyond doubt, and in addition to his works on economics and banking, ${ }^{235}$ he is also considered to have had a role in the drafting of the Iranian constitution. 236 Despite this, Sadr's revolutionary steps in the direction of a liberal and anti-formalist approach to Islamic jurisprudence is an important part of his legacy that cannot be gainsaid. ${ }^{237}$

231. Sanhuri's approach also reflects a certain civil law mentality given his crucial role in developing the civil codes in various Middle Eastern nations. Professor Fletcher has noted in a highly influential article that those steeped in common law culture engage in a type of "flat" thinking that emphasizes broad notions of reasonableness, while civilians prefer a "structured" approach wherein particular absolute rights, or in this case prohibitions, are established, but limited and qualified by doctrine. George $P$. Fletcher, The Right and The Reasonable, 98 HaRv. L. Rev. 949 (1984). This certainly seems to be the case here, as Sanhuri has established a blanket prohibition and then created particular exceptions based on "need," while the author's immediate common law reaction to Sanhuri's ideas turned to whether a multi-pronged balancing test concerning the reasonableness of the transaction might be a better approach. In any event, as Sanhuri and Sadr are highly influential figures in the Islamic world, the author prefers to engage their ideas to develop a sensible modality rather than simply adopt a pure flat approach with no precedent in Islamic jurisprudence.

232. See SanHuri, supra note 120.

233. See id.

234. See, e.g., Freamon, supra note 19, at 340-41 (describing Sadr's influence among Shi'ites); Mallat, supra note 17, at 124 (discussing his influence among Sunnis).

235. See supra note 17.

236. See Freamon, supra note 19 , at 341 .

237. Sadr was killed by Saddam Hussein in early April 1980, and he can hardly be faulted with all that went wrong in Iran, or Islamic finance, after his death. See Mottahedeh, supra note 72 , at 31 . 
One of Sadr's revolutionary proposals regarding hadith, ${ }^{238}$ which the author shall call the "contextual" approach or theory, involved an implicit bifurcation of Muhammad's activities conducted or advocated in speech or action, and those he is deemed to have accepted by failing to object when the practice was undertaken by others. ${ }^{239}$ Sadr argues that the latter must be evaluated in light of the circumstances in which the practice in question arose, and that failing to do so would be to commit the grievous jurisprudential error of "divorc[ing]. . . the practice from its conditions and circumstances." 240 For example, if Muhammad said nothing when a particular sick person drank something in his presence, then that would not make the consumption of the particular item permissible for all time. ${ }^{241}$ Study would have to be undertaken to determine whether Muhammad was permitting an exception based on an extraordinary disease, for example, or whether other conditions rendered the implied permission exceptional rather than general. ${ }^{242}$ Sadr argues that it is impossible simply to isolate a particular activity from the circumstances in which it arose. ${ }^{243}$ This is an implicit call for istislah to play a more significant role in jurisprudence. ${ }^{244}$ However, Sadr limits his theory to tacit approvals by Muhammad, not hadith where Muhammad clearly stated his approval of a particular activity. ${ }^{245}$

As with Sanhuri, Sadr shows an unmistakable willingness to lower certain hadith from their historic role as the source of fundamental principles, and his continued popularity notwithstanding this stance is notable. ${ }^{246}$ Moreover, his hadith-limiting contextual approach is capable of significant development if expanded to spoken hadith. The problematic manifestations of the doctrines of riba and gharar could be readily obliterated and replaced with more appealing interpretations. However, the expanded contextual approach has its difficulties, among them a lack of interpretive control, which the next section addresses.

238. Sadr advocated another idea concerning hadith that is considerably more radical namely, that the statements made by Muhammad in his role not as Divine Apostle, but as judge and administrator of his community, are not permanently binding on the Islamic community. Iqtisaduna, supra note 17 , at 262 . This idea opens entirely new possibilities and implications respecting hadith that are far too extensive to discuss here.

239. See IQTISADUNA, supra note 17 , at 370-71.

240. Id. at $370-72$ (translated by author).

241. See id. at 374 .

242. See id.

243. See id.

244. Sadr's calls for broader use of istislah are also implicit when he declares the need to develop a jurisprudence based not only on ethics (ikhlaqiyya), but also on realism (waqi'iyya), therefore distinguishing what he derides as Marxism developing idealistic and fanciful rules that assume selflessness and sinlessness and disregard the condition of human beings. See id. at 266. Sadr's assault on Marxist theory brings to mind the ideas of another pragmatist operating in the United States, Oliver Wendell Holmes, who famously derided the notion of law as being some sort of idealistic "brooding omnipresence in the sky." Southern Pacific Company v. Marie Jensen, 244 U.S. 205, 222 (1917) (Holmes, J., dissenting).

245. See IQTISADUNA, supra note 17 , at $372-75$.

246. See, e.g., Rodney Wilson, The Contribution of Muhammad Baqir al-Sadr to Contemporary Islamic Economic Thought, 9 J. IsLamiC STUD. 46, 46-47 (1998). 
C. Assertion of Interpretive Control within an Alternative Modality

1. A Problem of "Subjectivity"

Professor Fazlur Rahman has expressed some concerns about proposed expansive uses of istislah, noting in particular that it could lead to the creation of undue subjectivity. ${ }^{247}$ Sadr echoes the criticism and clearly struggles in Iqtisaduna to achieve a balance between the expansive form of creative jurisprudential thinking that he deems necessary to build an Islamic economic system, and what he calls dhatiyya, or subjectivity. ${ }^{248}$ The concern is that the assertion of some interpretive control will devolve into incoherence, with generalized Qur'anic verses effectively ignored or interpreted in a way that merely suits the particular interpreter's preferences.

Sanhuri's definitional approach manifests clear interpretive control, though it also continues to inhibit the development of Islamic finance. Sadr's contextual approach, if expanded to spoken hadith, is far more flexible, but could also create considerable problems regarding lack of interpretive control, as every hadith would then be reopen to evaluation with the only question of continued applicability being whether changed circumstances warranted it. It is difficult to see how this would not devolve into a jurisprudence of convenience and be dismissed as such.

\section{Proposed Synthesis of Definitionalism and Contextualism}

However, a synthesis of the two approaches is possible. One could apply Sanhuri's more reductive definitional method in principle, but in a slightly modified form in instances where the Qur'an did not define any particular practice as forbidden but rather defined a more general standard. After applying this definitional approach and reaching the logical conclusion that Sanhuri did, the jurist could apply Sadr's contextual theory to outline the prohibited practices at issue in a more contemporary fashion.

To take the example of riba, the argument would follow Sanhuri's definitional approach and define the Qur'anic prohibition, the intended prohibition, to be riba al-jahiliyya. Sanhuri originally stopped here because he reasoned that riba in the Qur'an was defined strictly as riba al-jahiliyya, and the Qur'anic ban could therefore not be disturbed. ${ }^{249}$ However, the argument could proceed, adopting Sadr's contextual theory that the particular intended prohibition of Muhammad's time is no longer an exploitative practice. ${ }^{250}$ Using a liberalized form of qiyas interspersed with istislah or istihsan, the extended conclusion would be that the prohibited activities of the Qur'an would no longer be the renegotiation of a debt but rather practices that are analogous to the intended prohibition in Muhammad's time

247. See Fazlur Rahman, Toward Reformulating the Methodology of Islamic Law, 12 N.Y.U. J. INT'L L. \& POL. 219, 223 (1979).

248. See IqTiSAdUna, supra note 17 , at 364-90.

249. See SANHURI, supra note 120 , at 172-73.

250. See lqTisaduna, supra note 17 , at $40-41$. 
but adapted to contemporary society. ${ }^{251}$ These would be situations where a party with enormous leverage over a second party exploits that leverage to its considerable gain and the first party's considerable loss. As for the prohibitions of means, Sadr's contextual approach could be used to determine other practices similar to the hadith under current circumstances that might be used as artifices to circumvent the intended prohibition. Trades that appear massively exploitative and one-sided, without direct evidence of excessive leverage, could be one example. This may be broad as a definitional matter, but hardly creates impossibly wide interpretive parameters over the term riba. Moreover, the synthesis promotes social justice by limiting the exploitative practices of Islamic financial institutions yet still defines those practices in a commercially practicable manner.

Gharar could be approached similarly, but with somewhat different results. The intended prohibition, as derived under the definitional approach, would be modern manifestations of games of chance, whose parameters seem rather self-evident. However, in evaluating the prohibition of means under the contextual approach, it is possible to imagine certain limitations on commercial activity. The basis for the limitation would be that the risks that certain activities entail do not justify the commercial purposes of the enterprise, and would thereby provide a means to circumvent the intended prohibition. ${ }^{252}$

These are simply illustrative examples; an entire modality would require considerably further exposition and methodological rigor by an interpretive community. However, by these examples, the author attempts to show how an experientially driven jurisprudence, grounded in traditional Islamic doctrine, could develop sensible legal rules without devolving into either the logic-driven quasi-scientific obsessions of Langdell or the nihilism of Critical Legal Theory.

\section{Fairness and Social Justice in an Islamic Context}

Given the importance to its ontology, Islamic banking is effectively senseless unless it provides some form of social justice and fairness. As financial institution patrons are likely Muslim, it is reasonable to assume that whatever form of social justice the institution exhibits should have particular Islamic characteristics. Riba and gharar, sensibly interpreted to prohibit particularly risky or exploitative practices, are not the only doctrines that might be used to promote this sort of fairness and social justice within an Islamic context, though they are among the most significant. Banks might take the mutual form as well to ensure their adherence to

251. This type of analogy is far removed from the original form of qiyas by which a rule was not so much modified as expanded. Nevertheless, the reasoning is analogical, and the use of the term qiyas is intentional, attempting to reflect some sort of proposed stability in the development of jurisprudential thought.

252. For example, this is not an unreasonable conclusion to reach with respect to day trading. The author also emphasizes again that these rules need not be enacted as law but rather could function as part of a voluntary financial or commercial system operating alongside a conventional one. See supra note 218. 
these new principles, as El-Gamal suggests. ${ }^{253}$ In addition, given the historic recognition of interest-free loans as acts of charity, Islamic banks could also be required to devote a small portion of their portfolio towards such loans to those in need. Islamic banks could refrain from investing assets in Islamically prohibited industries, such as those related to alcohol or gambling, and donate to legitimately charitable causes. Many of these doctrines are easy to develop and achieve, the only issue being their commercial practicability.

\section{Conclusion}

Islamic finance, as currently developed under the Langdellian formalism that defines Islamic jurisprudence, is an intellectually bankrupt construct. It has shown itself to be little more than an incoherent web of medieval rules, a convenient and specific blindness respecting those rules in particular contexts, and an obfuscatory set of measures intended to lend the entire affair a patina of genuine religious legitimacy. The goal was the creation of a fairer economic system rooted fundamentally in partnership profit-sharing. However, Islamic finance results in a system rife with unnecessary complexities and inconsistencies, decidedly more expensive than its standard commercial analogues and more deceptive given its highly exaggerated assertions of fairness, equity and, in some cases, charity. This has resulted from the application of formalistic interpretive systems with alleged origins in the jurisprudential theories of Shafi'i. As with the Langdellians in the United States, the quest for certainty, uniformity, and clarity, without regard to changing circumstances or considerations of policy, has led to the development of rules that simply cannot be applied directly, or even sensibly.

While an approach towards commercial jurisprudence that draws from more radical trends within the American Legal Realist paradigm seems impossible in the Islamic context, an alternative modality does seem possible, so long as it remains within particular parameters, among them a legitimate claim to faithful adherence to Qur'anic verse, substantial respect for the hadith, and sufficient systematization and methodological rigor to avoid what some Islamic jurists might deem subjectivity. More work is required to develop these ideas further.

Some may accuse the author of lifting longstanding prohibitions in the Islamic framework merely to satisfy global commercial demand. However, it seems clear from current experience that at some level the demands of the marketplace will reign supreme under any modality. The only question is whether to adopt a system that acknowledges this reality while retaining a distinctively Islamic character infused with populist notions of social justice and fairness, or to deceive the Muslim populace with elaborate obfuscatory measures intended to retain the form of profit-sharing while concealing the substantive reality of debt and risk-based finance. 
